Review

\title{
Towards a Conceptual Development of Industry 4.0, Servitisation, and Circular Economy: A Systematic Literature Review
}

\author{
Sehrish Atif ${ }^{1}\left(\mathbb{D}\right.$, Shehzad Ahmed ${ }^{1, *(D)}$, Muhammad Wasim ${ }^{1} \mathbb{D}$, Bassam Zeb ${ }^{1}$, Zeeshan Pervez ${ }^{2} \mathbb{D}$ \\ and Lorraine Quinn ${ }^{1}$
}

1 School of Business \& Creative Industries, University of the West of Scotland, Paisley PA1 2BE, UK; sehrish.atif@uws.ac.uk (S.A.); muhammad.wasim@uws.ac.uk (M.W.); bassam.zeb@uws.ac.uk (B.Z.); lorraine.quinn@uws.ac.uk (L.Q.)

2 School of Computing, Engineering and Physical Sciences, University of the West of Scotland, Paisley PA1 2BE, UK; zeeshan.pervez@uws.ac.uk

* Correspondence: shehzad.ahmed@uws.ac.uk

\section{check for} updates

Citation: Atif, S.; Ahmed, S.; Wasim, M.; Zeb, B.; Pervez, Z.; Quinn, L. Towards a Conceptual Development of Industry 4.0, Servitisation, and Circular Economy: A Systematic Literature Review. Sustainability 2021, 13, 6501. https://doi.org/10.3390/ su13116501

Academic Editors: Teresa Murino,

Eleonora Bottani, Daria Battini,

Marta Rinaldi and Luigi Roselli

Received: 31 March 2021

Accepted: 28 May 2021

Published: 7 June 2021

Publisher's Note: MDPI stays neutral with regard to jurisdictional claims in published maps and institutional affiliations.

Copyright: (c) 2021 by the authors. Licensee MDPI, Basel, Switzerland. This article is an open access article distributed under the terms and conditions of the Creative Commons Attribution (CC BY) license (https:// creativecommons.org/licenses/by/ $4.0 /)$.
Abstract: Industry 4.0 (I4.0) technologies have been highlighted in recent literature as enablers of servitisation. Simultaneously, businesses are advised to implement a circular economy (CE) to bring new opportunities. However, it is pertinent to mention that little attention has been given to assess the role of I4.0 in adopting the CE and servitisation in a fully integrated manner. This research fills this gap by developing a conceptual framework through a systematic literature review of 139 studies investigating the relationship between the I4.0, CE, and servitisation. This study identifies the impact of these variables on a firm's operational and financial performance (revenue stream, growth, and profitability). Our research findings advocate that adopting I4.0 technologies to the business and manufacturing model enables sustainability, energy and resource efficiency while enhancing performance and offering innovative products through smart services. Thus, firms must systematically adopt I4.0 technologies to support a CE model that creates value through servitisation. This study identifies the research gaps that are unexplored for practitioners and future researchers while providing insight into the role of I4.0 in implementing CE in the servitisation business model.

Keywords: circular economy; internet of things; Industry 4.0; servitisation

\section{Introduction}

Technology plays a vital role in today's dynamic world. It continuously transforms how organisations operate by reshaping products, processes, services, strategies and adopting sustainable business models to perform better [1-3]. The fourth industrial revolution, called Industry 4.0 (I4.0), integrates IoT, cloud computing, cyber-physical systems (CPS), smart manufacturing/factories, artificial intelligence (AI) and big data analytics for value creation that enables the binding of a smart, decentralised, and digitised value chain [4]. Innovative products with high functionality are in great demand with enhanced technological advancement that utilises cautious resources (capital resources, human resources, and material resources). Therefore, I4.0 has been deliberated as a suitable solution for addressing contemporary issues such as innovation cycles, enhanced demand volatility, and increasing customisation [5]. The primary focus of this integration is to modify a business model (BM) while providing new revenues and value-producing opportunities that reduce a product's manufacturing time and efforts [6].

In addition to this, industrial organisations are expected to create sustainable value, such as contributing to society by pursuing social, ecological, and economic objectives as the circular economy (CE) [7]. In simple terms, I4.0 plays a critical role in strengthening and maintaining future global competitiveness [8]. I4.0 is an innovative approach that adds value to manufacturing processes and thus possesses a marked improvement for its 
sustainability [9] and supports servitisation [10]. Therefore, it is within the interests of businesses to enable and enhance technical development within the BM. This vision aims at higher flexibility, and improved quality and commercial (economic) returns to gain a competitive market advantage [4].

A common perception among academics is that this revolution will create digitally enhanced machines that will efficiently substitute human labour [11]. The usage of these intelligent machines comes under servitisation and subsequently improves an organisation's overall performance [12]. Industries continuously work towards increasing production, but they have been trying to do so by providing products alone without technology-enabled services in the past years. [8]. Hence, in today's competitive market, I4.0 technologies possess the potential to catalyse the rapid development of the CE paradigm through specialised service design. Servitisation disrupts the economy and forces it to evolve by advancing technology, creating professional employment opportunities, opening new markets, and boosting goods and services through sustainable life-cycle integration [13]. This systematic transformation is based on the CE paradigm that generates revenue from an undervalued waste stream [14]. It encompasses organisations' innovative techniques to use energy, resources, and materials while reducing their environmental impact $[3,4]$ efficiently and effectively. Questions remain regarding how to manage this progressive integration solution.

The academics and practitioners actively adapt to the CE paradigm and adopt pivotal technologies to enhance their operational efficiency and financial performance [15]. This unprecedented change persuades firms to adopt digitalisation through software empowered products [16]. CE's comprehensive methodology provides organisations with environmental, social, and monetary benefits when it replaces the traditional linear-economy model [17]. At the same time, servitisation offers "outcome as a service" instead of a one-off sale [18]. Consequently, in today's competitive world, the demand for the next generation of intelligent products with improved functionality and value-added services is rising $[19,20]$. Products must be integrated with closed-loop processes across the supply chain [21], and service provision constitutes a massive share in the revenue stream for manufacturers [22,23].

The focus of this study is to find the answer to the following research questions: what are the focal discoveries by previous researchers of (i) I4.0, (ii) servitisation, and (iii) CE? How do firms perceive the collective potentials of combining them? The literature review presented in this paper explores the relationship among the key variables, i.e., I4.0, servitisation, and $\mathrm{CE}$, to investigate the disposition of this fast-moving global revolution. It also analyses how this relationship influences firms' operational and financial performance to clarify the impact and consequences of the above-mentioned three megatrends. The preliminary part of this paper will briefly explain the main variables of this research study. Furthermore, this paper will present an in-depth, cross-theme analysis of the variables and evaluate their relationship.

This paper is structured as follows; Section 2 briefly describes the methodology adopted to conduct this research and explains the selection process of the articles. Section 3 presents a combined summary of the literature related to the key variables: I4.0, servitisation, and $\mathrm{CE}$, and their relationship-investigating their impact on the performance of firms. Finally, Section 4 presents the discussion and conclusion, including practical and research gaps relevant for future investigation.

\section{Research Methodology}

The systematic literature review (SLR) approach has been widely used in the multidisciplinary domain to investigate the in-depth knowledge of research findings from various studies $[24,25]$. The critical principle of SLR is transparency and inclusivity, which logically initiates research to conduct a rational and objective stance from previous research [26]. This paper uses the methodology suggested by Fisch [27] to conduct a transparent SLR. 
This method supports building a conceptual foundation of this paper's key variables (I4.0, servitisation, and $\mathrm{CE}$ ).

\subsection{Steps of Systematic Literature Review}

The authors have followed the planning, execution, and reporting principles suggested by Tranfield [24] in conducting an SLR. A list was articulated containing all the elements of the selected papers. It helped the authors to scrutinise the information from variant perspectives. Figure 1 depicts the steps used in this study to conduct the SLR.

\section{Step 1: Defining the Research scope and setting the Research objective}

Scope: To conduct the literature review on the key elements (Industry 4.0, Servitisation, and Circular Economy).

Objective: Evaluation and outlining of existing research and scrutinising the thematic analysis of the relationship among the key variable.

\section{$\downarrow$}

\section{Step 2: Selecting the Keywords and the Databases}

Searching the keywords (Initially 8 keywords were used that were refined into 5 combinations) on database (Emerald, Science Direct, Scopus, and Web of Science) that are relevant to the research topic within a pre-decided time period (2013-2021).

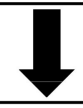

Step 3: Setting quality attributes through Inclusive and exclusive Criteria Including the articles based on 4 Quality Attributes (QAs)

Excluding the articles that were off-topic, non-English and not peer-reviewed.

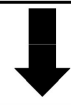

\section{Step 4: Interpretation and presentation of the findings}

Analysing the three key varibles (I4.0, CE and Servitisation)

Investigating the link among the key variables (I4.0 and CE; I4.0 and Servitisation, CE and Servitisation)

Examining the impact of the combination of the key variables (I4.0, CE and Servisation) on firm's performance.

Figure 1. Steps in the systematic literature review.

The first step of an SLR is to determine the research scope and identify key objectives [27]. This research study aims to analyse the previous research to identify key characteristics and the novelty of the variables (I4.0, servitisation, and CE) and the relationship among the key variables. Then, the paper assesses the impact of the key variables on firm performance. 
The second step involves screening the relevant articles for analysis. There is a high chance of systematic error in this phase, and so the authors used Newbert's inclusive and exclusive criteria for selection [28]. After several brainstorming sittings among the authors, eight keywords related to the research domain were selected that met the screening criteria, i.e., I4.0, the fourth industrial revolution, smart manufacturing, internet of things (IoT), digitalisation, servitisation, product-service system, and CE. Later these keywords were refined by different combinations, for instance, "CE and/or I4.0", "CE and/or servitisation", "CE and/or IoT", "I4.0 and/or servitisation", "I4.0 and/or CE and/or servitisation". One hundred and thirty-nine articles were extracted and analysed to identify the patterns, directions, comparations, and variances related to the key variables of this study (I4.0, CE, and servitisation).

The focal goal of this study was to investigate the key variables (I4.0, servitisation, and $(E)$, their relationship, and their impact on performance. Thus, the third step was selecting relevant publications from the selected databases in a predefined period (from 2013 to the first quarter of 2021). The four databases that were used were Emerald, Science Direct, Scopus, and Web of Science. The journal articles from these databases are of high quality as they are peer-reviewed. From searching these databases, it is clear that the key variables used in this paper (I4.0, CE, and servitisation) are currently receiving increased attention from academics and practitioners [1,16,29].

The fourth step involves validating the quality of the search protocol followed in conducting this research to ensure data validity and reliability. This study used Newbert's [28] inclusive and exclusive criteria to shortlist the relevant papers:

- $\quad$ Empirical research papers in the business and management discipline.

- Multidisciplinary empirical papers on I4.0, CE, and servitisation, especially business and management discipline (including supply-chain management).

- $\quad$ Papers only selected from peer-reviewed scientific journals published in English.

- Non-academic papers such as white papers, industry magazine papers, and personal blogs were excluded.

- Articles with at least one keyword (I4.0 or/and servitisation or/and CE) in the title or abstract were selected to ensure relevance.

- Duplicates and papers published outside the specified period (from 2013 to the first quarter of 2021) were excluded.

The authors utilized an architecting software system known as Quality Attributes (QA), as Agarwal [30], to conduct the study. It includes a series of checklist questions that limit errors and biases. The four QAs used to ensure the validity and reliability of the research, eliminating potential subjective prejudices, are:

- QA1: Do the selected papers discuss any I4.0 technologies or/and servitisation or/and CE or CEBM?

- $\quad$ QA2: Does the selected paper related to the key variables (I4.0, CE, and servitisation)?

- QA3: Does the selected paper discuss the relationship among the key variables (I4.0, $\mathrm{CE}$, and servitisation)?

- QA4: Do the selected paper findings, results, and conclusion correspond to our research domain?

\subsection{Methodology Process}

The research began by selecting four databases (Emerald, Science Direct, Scopus, and Web of Science) and one search engine, i.e., "Google Scholar", to extract the relevant research papers. The following databases are believed to be highly credential for holding scientific publications from all over the world.

The initial research started by searching the keywords (I4.0, servitisation, and CE) to select the papers for review. Figure 2 shows a PRISMA flow diagram and explains the rigorous process followed in the selection of papers. The authors found 4301 papers overall within the databases and selected 1965. Various filters were used to refine the keywords with Boolean logic, concentrating the search to 614 papers. 


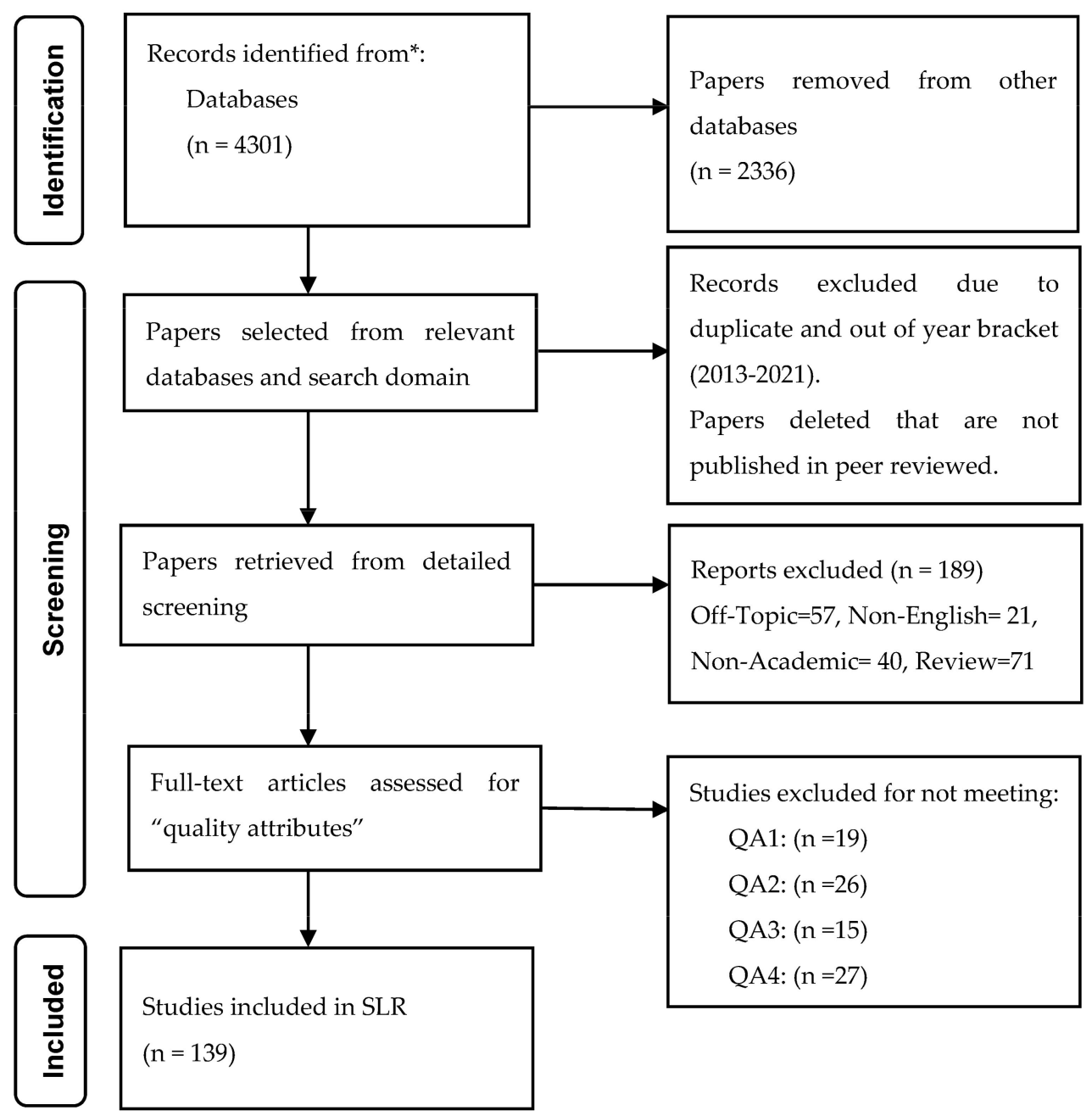

Figure 2. PRISMA flow diagram showing the search and screening process.

The authors decided to apply inclusive and exclusive criteria to these selected papers' search process and quality attributes. This step excluded papers that were less scientifically rigorous or irrelevant for this study. This resulted in a final 415 papers left for analysis. After reading the content of these papers, the authors finalised the relevant papers for the ultimate selection. The authors were left with 139 papers that met the criteria and were explicitly related to the theme of this study. Table 1 highlights the methodology process that the authors adopted to select the most relevant papers for this research:

Table 1. Summary of the methodology process.

\begin{tabular}{|c|c|c|c|c|c|}
\hline & Scopus & $\begin{array}{c}\text { Web } \\
\text { of Science }\end{array}$ & Science Direct & Emerald & Total \\
\hline $\begin{array}{l}\text { Step 1: Keywords } \\
\text { Industry 4.0, servitisation, and circular economy. }\end{array}$ & 2069 & 1205 & 699 & 327 & 4301 \\
\hline $\begin{array}{l}\text { Step 2: Theme } \\
\text { Managerial approach: literature related to business } \\
\text { models, supply chains, or firm's value chains. }\end{array}$ & 798 & 403 & 549 & 215 & 1965 \\
\hline $\begin{array}{l}\text { Step 3: Incl. and Excl. Criteria } \\
\text { Off-topic, non-peer-reviewed, non-English, duplicate. }\end{array}$ & 86 & 78 & 39 & 23 & 226 \\
\hline $\begin{array}{l}\text { Step 4: Selected Papers } \\
\text { Finalized paper for review }\end{array}$ & 49 & 32 & 46 & 12 & 139 \\
\hline
\end{tabular}




\subsubsection{Analysis Process}

The selected papers finalised for review were unwaveringly related to the key variables (I4.0, servitisation, and CE). The next step was to archive and classify them into a research matrix prepared on an excel sheet. The authors conducted a rigorous analysis to retrieve valuable information that comprehended their domain. These papers were categorised according to the journal name, year of publication (2013-first quarter of 2021), authors, theme (main focus of the research), type of paper (empirical or conceptual frameworks), design, applied methodology (systematic literature review, qualitative, or quantitative), sample size (population or unit analyses), research gap (for future researchers), and the results.

The research matrix made it easier for the authors to cover I4.0, servitisation, and $\mathrm{CE}$ from various standpoints. There were three exclusive features identified from the review: (i) Most of the papers had been established or developed using two of the three variables (I4.0, and/or servitisation, and/or CE); (ii) Most of the papers included theoretical framework or case studies using qualitative research techniques from developed countries; and (iii) Most of the papers were undertaken from the perspective of customer value or firm's downstream operations. These judgments lead the authors to identify and develop the conceptual views in the domain of the key variables (I4.0, servitisation, and CE). The classification of the analysis process of the finalised papers that were used in this study can be divided into the following sections:

- Keyword analysis

- Descriptive analysis

- Methodology analysis

\subsubsection{Keyword Analysis}

The keyword analysis holds significant importance in the paper. It transpires the focus area of a research paper. Several keywords were identified; the clustering of these keywords helped the authors to set them into categories. The keyword categorisation process used in this paper is described in Figure 3.

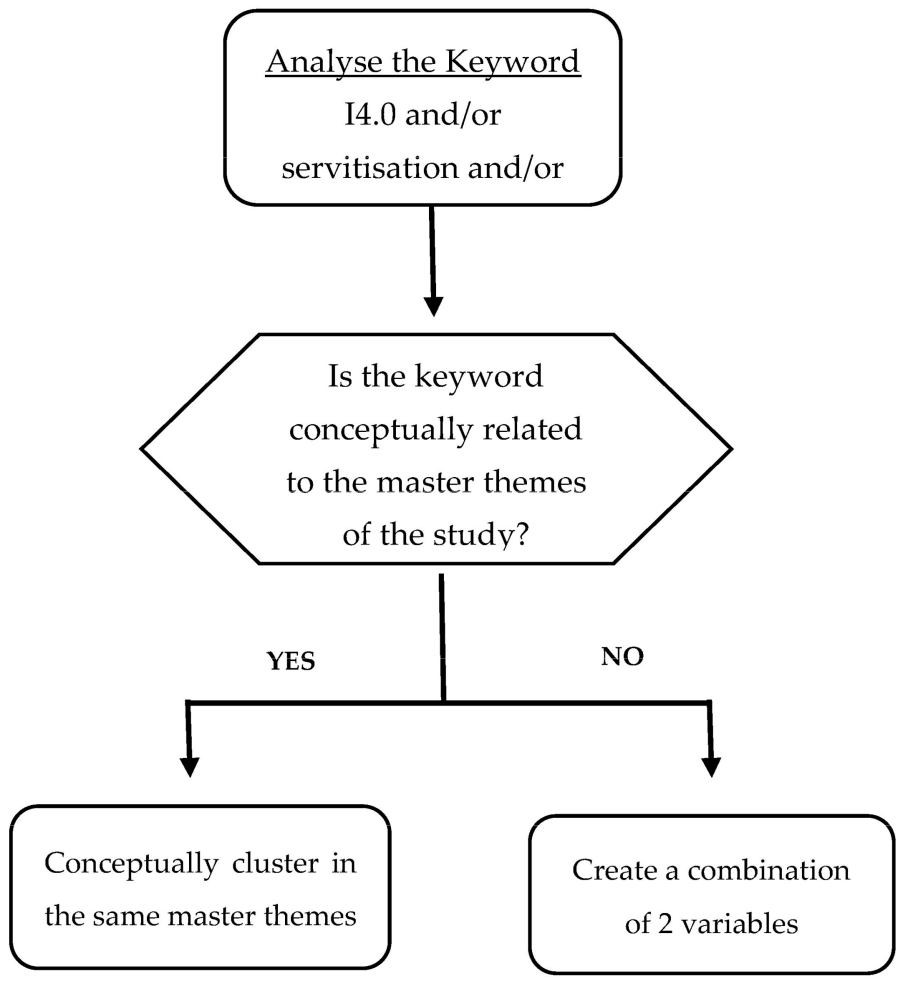

Figure 3. Keyword categorisation process. 
The authors cited various keywords during the analysis process, such as the internet of things (IoT), cyber-physical System (CPS), smart manufacturing, smart factory, productservice system (PSS), sustainability, and circular BM. These come under the master themes: (i) the role of I4.0, (ii) servitisation, and (iii) CE. The authors then conceptualised the master theme as the hybrid of the three key variables (I4.0, servitisation and CE).

Consequently, this paper indicated three distinct research areas in which the authors investigated how this combination of variables meets, captures, and delivers new value to all stakeholders. The authors reviewed the 139 papers in detail. Each paper was categorised depending on its primary focus and subsequently set into first-order thematic categories according to the key variables (I4.0, servitisation, and CE). They were then further grouped into a second-order analysis representing the key variables' hybrid categories (I4.0 and/or servitisation; I4.0 and/or CE; servitisation and/or CE).

\subsubsection{Descriptive Analysis}

The authors selected relevant papers that were published between 2013 to the first quarter of 2021.

Figure 4 demonstrates the database-wise analysis of the finalised papers relevant to this study. Most of the articles originated from Scopus, whereas the lowest number of articles came from the Emerald database. Figure 5 showcases the distribution of journals in which the finalised 139 papers used by the authors to conduct this SLR were published.

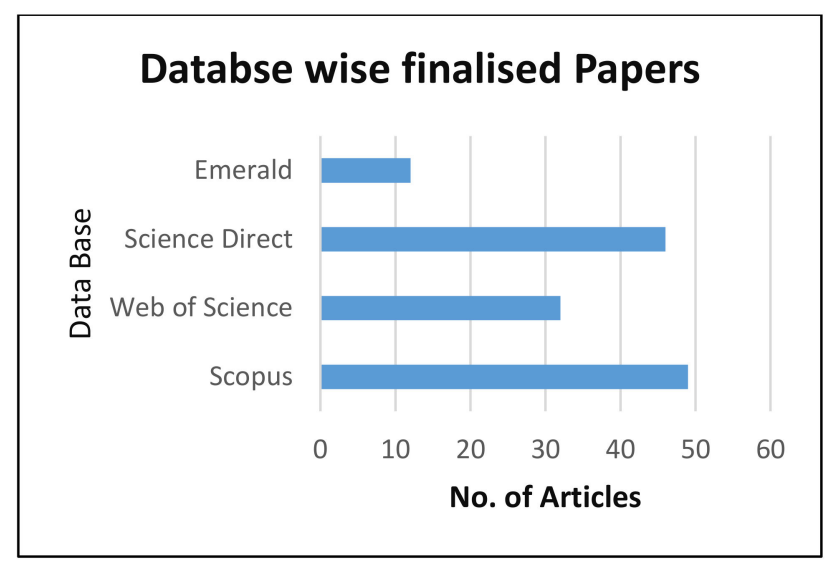

Figure 4. Database-wise finalized papers.

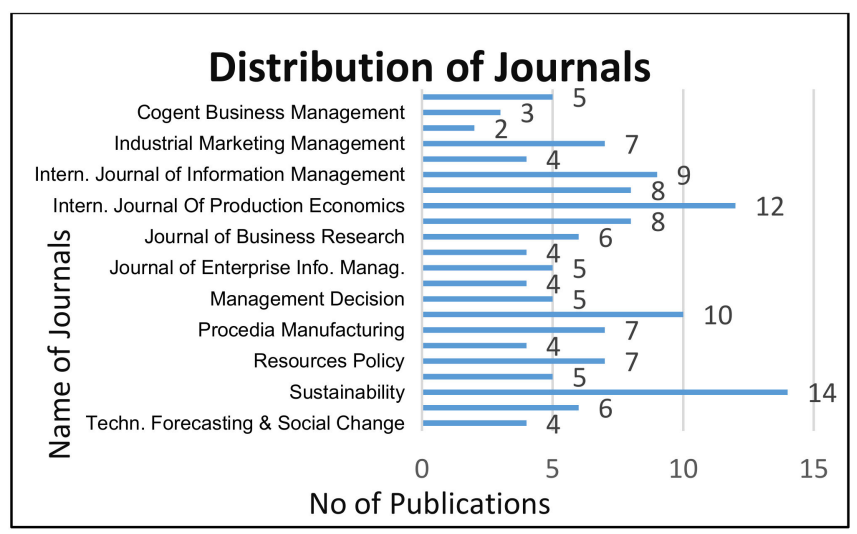

Figure 5. Distribution of journals in which the finalised papers were published.

It is evident from Figure 6 that there has been regular research on servitisation within the literature over the years. In contrast, I4.0 and CE literature has only received particular attention among researchers in recent years. The government and practitioners are giving a lot of consideration to investigating the potential of I4.0 technologies in firms that adopt a CE. 


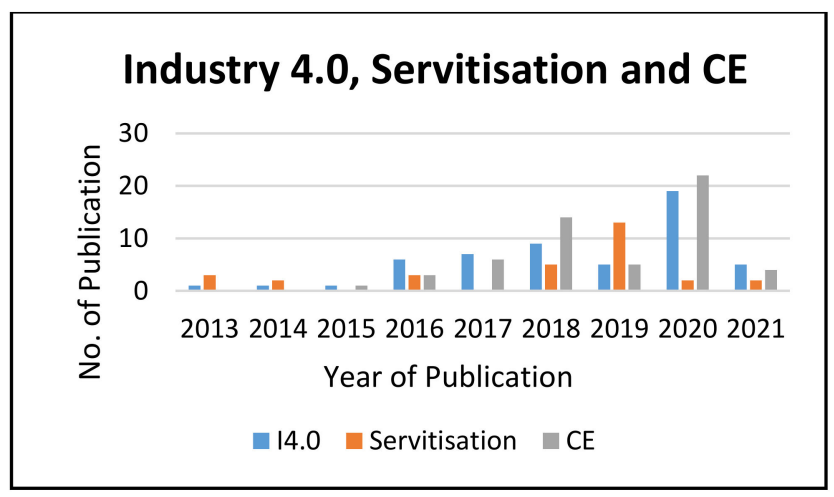

Figure 6. Yearly published papers on I4.0, servitisation, and CE.

Researchers and scholars from all over the world publish their research work on these databases. It is vital to understand the geographic location of the authors. The authors have used inclusive and exclusive criteria for selecting the relevant papers. It is evident from the literature on servitisation that it has been covered almost equally worldwide, as shown in Figure 7.

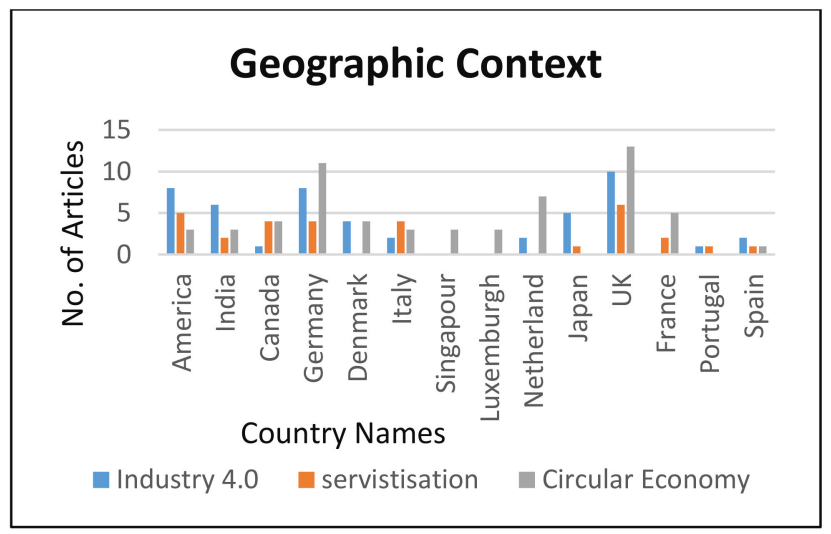

Figure 7. Geographic context of the articles published on I4.0, servitisation, and CE.

In contrast, most of the articles related to I4.0 originate in early years from the Germany, as the term "Industry 4.0" was coined in Germany, as showed in Figure 7. In comparison, the USA and the UK hold the most significant share in providing technological services. Figure 7 also showed that the articles on the CE paradigm are published mainly by authors from the Netherlands, France, the UK, and Italy.

\subsubsection{Methodology Analysis}

After conducting descriptive and keyword analysis, the authors categorised the papers according to their adopted design and applied methodology. It is evident from Figure 8 that among 139 papers selected for the SLR, 23\% of the I4.0 and/or CE and/or servitisation papers are literature reviews (systematic or narrative). In contrast, case studies are applied to $46 \%$ of the papers. The authors have adopted the qualitative approach by interviewing the related firms that have adopted the $\mathrm{CE}$ and are service providers.

The authors identified a research gap in the current literature, suggesting that most future researchers should adopt a mixed-method approach when conducting case study methodology to validate outcomes. It can be said that I4.0 and CE literature is comparatively new; thus, researchers are still developing the conceptual or theoretical framework. In contrast, service-related papers are mostly case study based, where the authors have tried to understand the orientation through employees' experience. 


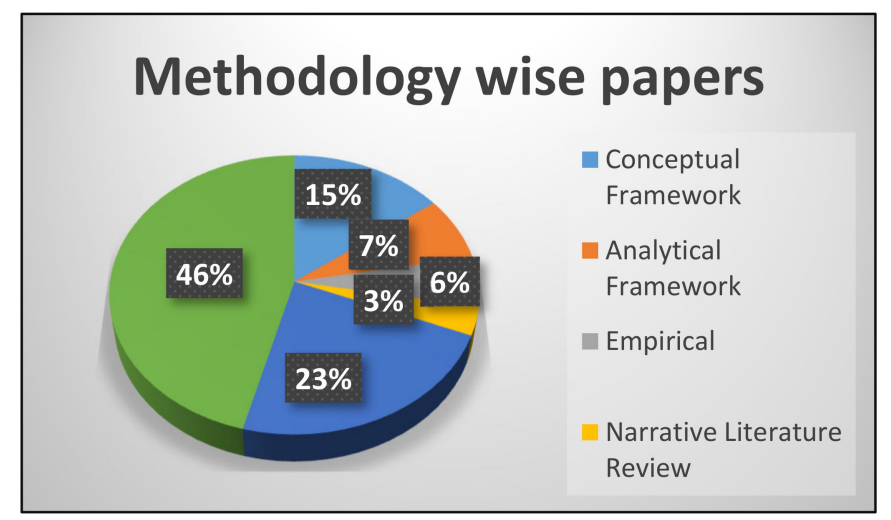

Figure 8. The design and applied methodology of the selected papers.

\section{Results}

The SLR results are characterised into three groups. Firstly, how the key variables (I4.0, servitisation, and $\mathrm{CE}$ ) have been studied in the business and management domain. The second objective is to analyses their hybrid affiliation by investigating how each variable plays a role in enabling another. Lastly, an in-depth analysis of how I4.0, servitisation, and CE impact a firm's performance.

\subsection{Key Variables}

This section discusses the three main concepts, I4.0, servitisation, and CE. A brief description of these concepts is presented below.

\subsubsection{Industry 4.0}

I4.0 technologies (IoT, cloud computing, predictive analytics, and big data) offers a sophisticated interconnected platform that combines hardware and software [31,32]. A general assertion shared among scholars and researchers is that 14.0 connects the physical and digital world $[4,12,16]$. IoT technologies in industrial manufacturing and production systems help digitalise these systems [33] and contribute to value creation [34].

I4.0 was initially developed in 2011 as a zero-sum method based on the impact of innovation [16,35] on future production systems and as a scheme to establish Germany's competitiveness in the fourth period of economic change [35]. The term "I4.0" was coined by Klaus Schwab, a German industrial strategist, in 2015 [36]. It provides an intrinsically accessible platform for businesses to adapt to unforeseeable market conditions [15].

It supports management processes by streamlining decision-making about operations, digital transformations and enhancing the customer experience while improving the return on investment [4]. It was founded on the principle of intelligent, vertical, horizontal, and real-time connections of machines, people, information, objects, and communication systems to manage complex systems vigorously [28].

From the I4.0 literature analysis, it is noted that the present increasing attention and interest of organisations in I4.0 technologies encapsulate the technical foundations of its general implications on business [2,3,37]. Most studies focus on the challenges of I4.0 for organisations [36,38], in the form of reviews or opinions that critically relate to BM designs [39-41] and how I4.0 can help organisations' deliver, capture, and create value in this context [4]. The vital influence of I4.0 in BMs has critically received limited attention from researchers [16,42].

In a BM, the value proposition is being reformed by the technology known as I4.0 that critically contributes towards improving consumer operations procedures [8]. Experts believe 14.0 is a cluster of opportunities [28,43]. This perception aligns with the results gathered from papers that indicate that 14.0 supports firms in improving their performance $[12,44,45]$. Another common perception within the literature is related to the role of 14.0 technologies adapted for different roles within a firm [35]. The analysis 
showcases a positive outcome on the internal infrastructure within a business management context [12], the principal constituent of the business operations model $[14,46]$, and customer relationship management $[12,47]$ when the system is accustomed accordingly.

Likewise, Rymaszewska [1] suggested a service-based operating model that essentially constitutes the manufacturing assets and provision of production along with associated analytics services, full-service operations, information services, and efficient mass customisation via end-user integration. Presently in companies or factories using I4.0, equipment is connected as a collaborative community [48].

This type of evolution supports the usage of advanced prediction devices [10,32,49]. Data gathered can be methodically administered to identify uncertainties and develop wellversed solutions to overcome barriers to a more collaborative, sustainable, and resilient supply-chain network $[10,50]$. Thus, it can be said that I4.0 is an advanced version of predominantly information technology (IT) that drives transformations in the current manufacturing operations and systems [37,38,51]. Experts have also shown consensus about 14.0, suggesting that such development not only infuses technological advancement but is accompanied by versatile organisational repercussions as well [12,21,52].

\subsubsection{Servitisation}

Industries and manufacturing organisations are encountering many changes and revolutions resulting from the past few decades. Technology has changed the criteria related to how organisations do business with customers and develop, supply, and manufacture products [34]. The two existing macro-phenomena I4.0 and servitisation have an impact on and significantly challenge organisations' BMs.

Servitisation is principally linked to the demand-pull innovation trajectory [34]. As the present industries and markets shift from product consumption towards result-oriented demand, consumers anticipate receiving supplementary services that improve their overall experience while making purchases or getting in touch with their goods and services [1].

In some situations, rather than finding ways to pay for the product or services itself, the consumer wants to obtain the worth integrally presented using the merchandise, consequently using it as a service [53]. This drastic transformation has resulted in the introduction of servitisation approaches within manufacturing organisations, including initiating a shifting from the product-centred organisations towards the PSS [54]. PSS and servitisation are used alternatively in the literature [55].

PSS is customer-focused and substantially impacts product development, life-cycle management, and cost analysis $[13,56,57]$. Servitisation is defined as the transformation procedure from the product-centric towards a service-oriented BM [55]; servitisation defines the productivity of this process [8]. It integrates services and goods that offer diverse functionalities to stakeholders and consumers and offer environmental advantages [58].

According to Witell et al. [59] and Kuhl et al. [60], transformations are significantly rooted in the value architecture of organisations. They consist of value creation, capture mechanisms, delivery, acting, and complementarities as a manifestation of a company's business approaches that are critically referred to as business model innovation (BMI).

The most common understanding of servitisation is that it brings competitive and strategic aids for implementing this innovated BM [61]. Several research papers have deliberated a relationship of servitisation within the manufacturing industry $[1,18,62]$, and further researches in this domain have significantly increased in the past two decades $[18,61]$. There are different definitions for the term servitisation; we have picked the one more relevant to our research studies given in Table 2.

Servitisation is one of the cost-effective megatrends of the present technological society [61]. It is a process that helps create value for the manufactured goods by adding services to products [1]. This current and rising megatrend of the BM is called servitisation $[13,63,64]$. Many companies have initiated models that have machines and products with intelligent digital systems to operate and communicate with other devices and systems 
independently $[13,32,65]$. As a result of this growing trend, many companies have started to use digital systems $[12,66]$ to offer various services to their clients and customers [18].

Table 2. Definition of servitisation.

\begin{tabular}{cc}
\hline Author & Definition \\
\hline Tim Baines [13] & $\begin{array}{r}\text { "Servitisation is the concept of manufacturers offering services } \\
\text { tightly coupled to their products". }\end{array}$ \\
\hline Andy Neely [22] & $\begin{array}{c}\text { "The innovation of organisations' capabilities and processes to } \\
\text { better create mutual value through a shift from selling products to } \\
\text { selling PSSs". }\end{array}$ \\
\hline Bart van Looy [62] & "A trend in which manufacturing firms adopt more and more \\
service components in their offerings".
\end{tabular}

\subsubsection{Circular Economy}

The current dominant economic development model, known as the "take, make, and dispose of" model, is presently being questioned [67]. On both the global and regional level, sustainable methods of managing and consuming provisions and natural resources have become significantly important [68]. As Majeed [3] suggested, resource intake's dominant economic development model is dependent on carrying out business activities by utilising material resources.

Throughout the diversification and evolution of the linear economy, the industrial economy had hardly moved away from the initially established primary characteristics developed in the preliminary days of industrialism [69]. When companies use the linear model, they harvest, extract, manufacture, and sell products in the market, and subsequently, these are entirely discarded when no longer used [67]. The linear model depends on the excessive availability of resources; therefore, there is an immense need to change its entire operation [70].

According to Kristensen [70], "The CE has gained traction as a pathway towards more sustainable economic growth". CE is referred to as an industrial economy that aims to be restorative, critically relies on alternate energy, reduces, eliminates and tracks the utilisation of toxic substances, and reduces waste via cautious design $[4,68]$. The $C E$ concept goes beyond the mechanics of consumption and production of products and services, particularly in areas that need to be redefined, such as rebuilding capital involving natural and social aspects and shifting clients from customers to users [52,57]. The perception of the $\mathrm{CE}$ is initiated from the study of non-linear systems, specifically the living ones [52].

Copani [71] explain that the idea of circular suggests embracing new techniques for industries and organisations that create value not previously attained for both the consumers and the company itself. The principles of CE entailing the 10R-strategy explain ways for value creation, such as re-using the used product or using its component as a by-product for a new product; rethinking the BM; reducing the usage of virgin resources and enhancing efficiency; reusing a used product by outsourcing; repairing and maintenance of a defected product; refurbishing and restoring products through upgrades; remanufacturing, i.e., using a component of the discarded product in a new product with same functionality; repurposing a redundant product with different functionality, and recycling of products or materials [52,72].

Consequently, De Moura [61] claimed that this idea of CE proposes that the synchronised formation of economic and environmental benefits can produce employment opportunities in the industry. These sustainable financial goals will directly contribute to employment creation where businesses acquire human resources to take care of related services [70]. 


\subsection{Relationship Among the Three Key Variables}

The second objective of this SLR is to understand how each variable plays a role in enabling the other variable and vice versa. Initially, of the 139 scientific articles were selected, 40 described the direct and indirect relationships between I4.0 and servitisation. The authors identified that 68 papers described the relationship between I4.0 and CE, and 31 articles dealt with the relationship between servitisation and the CE. An initial overview of the literature was undertaken from various perspectives to test the link between these three key variables.

\subsubsection{Linking I4.0 and Servitisation}

The current literature relating to servitisation has given unprecedented prominence to understanding organisation-level success and failure $[1,61]$. It nurtures innovation within business operations as they expand their scope by introducing value-added services [73]. Since it considers the heterogeneous resources of organisations [74], it should be noted that an appropriative infrastructure helps in identifying innovation requirements that enable the effective dispersal of technological innovations [8,71,75]. Commonly, I4.0 improves online scheduling and monitoring systems by deciding on the most acceptable parameters $[32,45,51]$. Using a cloud-operated dashboard aids timely service interference for manufacturing process alterations $[9,76,77]$.

Bal [78] and Seddon [79] indicated that adapting the lease-first-then-sell (LFTS) concept enhances the profit because remanufactured components decrease production costs, leading to an increase in income [80]. Meanwhile, Schroeder [10] presented an integrated PSS from a life-cycle perspective to reduce costs and associated service disruptions. Thus, the integration of efficient products $[71,81,82]$ and competent services must be accompanied by a supportive network that ensures the disposability of offerings of servitisation $[50,83]$. For example, 3D printers are frequently presented as additive manufacturing (as one of the I4.0 technologies). This technology supports servitisation because firms take them on lease from a third party instead of buying them, maximising the value of exploiting and reallocating cyber-physical resources $[62,65]$.

Evidence from Table 3 (below) advocates that this disruption caused by adopting the $\mathrm{CE}$ revolves around supply-chain management. Consequently, preventing unnecessary material flow by optimising or reducing supply-chain activities results in higher economic rewards $[55,76,78,79]$. Therefore, innovative product design would facilitate reusing, refurbishing, upgrading, and maintaining products [80]. The I4.0 and servitisation literature are still in development $[1,81]$. Several studies consider servitisation as the only transformation in the broader sense that helps create value by integrating I4.0 technologies $[1,65,82,83]$. Businesses must integrate servitisation features into their strategy and ensure an excellent supply-chain network for sustainability that avoids unnecessary disruption [80]. 
Table 3. Key studies in the research domain discussing how I4.0 enables servitisation and vice versa.

\begin{tabular}{|c|c|c|c|c|c|c|c|c|c|c|c|c|c|c|c|}
\hline $\begin{array}{c}\text { I4.0 and Servitisation } \\
\text { References }\end{array}$ & 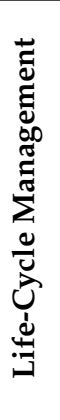 & 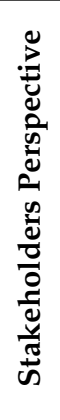 & 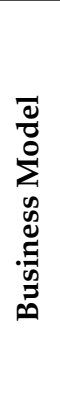 & 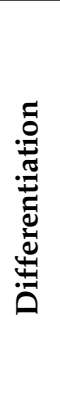 & 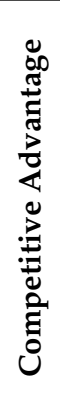 & 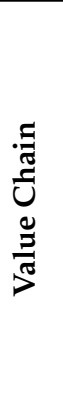 & 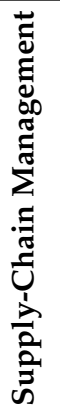 & 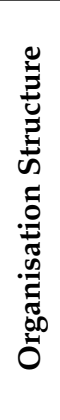 & 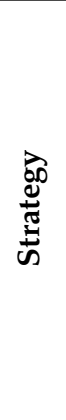 & 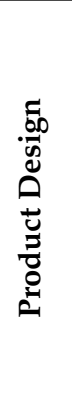 & 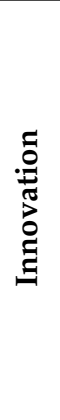 & 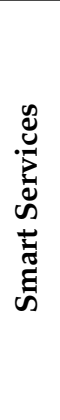 & 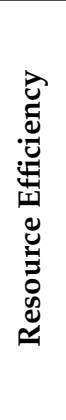 & 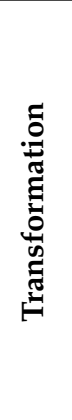 & 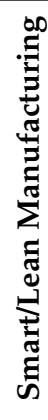 \\
\hline [1] & & & $x$ & $x$ & & & & $x$ & & & & & & & \\
\hline [9] & $x$ & & & & & & $x$ & & & & $x$ & & & & \\
\hline [49] & & & & & & $x$ & & & & & $x$ & $x$ & & & \\
\hline [62] & & & $x$ & & & $x$ & & & & & & & & & \\
\hline [69] & & & $x$ & & & & $x$ & & & $x$ & & & & & $x$ \\
\hline [70] & & $x$ & $x$ & & & $x$ & & & & & & $x$ & & & \\
\hline [78] & & & $x$ & & & & $x$ & & & & & & & & \\
\hline [84] & & $x$ & $x$ & & & & & $x$ & & & $x$ & & $x$ & & \\
\hline [85] & & & & & & $x$ & & & & & $x$ & $x$ & & & \\
\hline [86] & & & & & & & & $x$ & & & & & & & \\
\hline [87] & & & & $x$ & & $x$ & $x$ & & & & $x$ & & & & \\
\hline [88] & & & & & & & $x$ & $x$ & $x$ & & & & & & \\
\hline
\end{tabular}

\subsubsection{Linking $\mathrm{I} 4.0$ and $\mathrm{CE}$}

The manufacturing industry is experiencing an immediate revolution from a linear to a circular economic model [89]. Self-optimisation and self-configuration play a significant role in making the system more dynamic and efficient [90]. According to Rehman [45], the critical attributes identified for I4.0 include scalability, interfacing, security, quality of service (QoS), reliability, modularity, networking capabilities, integration, and interoperability.

The transition from a linear to CE results in a notable shift in the market/customer segment. Therefore, to achieve maximum customer value, firms invest heavily in I4.0 technologies by integrating full value networks and transparency of systems [37,50,91,92]. To explain the relationship between I4.0 and CE, most experts have used the term "Digitalisation of CE" $[28,33,36,93]$.

The majority of the business studies-related literature highlights that firms have a dual responsibility [94-97]. The first and foremost aim is to produce a substantial return on investment $[4,98,99]$. The other is to eliminate any negative environmental impact while enhancing social acceptability in the new market [100-102].

I4.0 offers a path for firms to apprehend a sustainable spot in the market through innovative development, primarily through smart manufacturing [103]. There is a consensus among researchers that the development of information and communication technologies brought about by I4.0 can subsidise sustainable manufacturing through using examples mostly from developed countries [22,100,104]. Saberi [91] suggested that I4.0 technologies such as IoT and blockchains are significant innovations that drive sustainable business systems [68].

According to Govindan [105], infrastructure creation, policies [106], and laws [107] to promote sustainable businesses are critically regarded as significant for the integration of I4.0 [15,38,48]. It is evident from the analysis that few authors insist about policyenforcement or law binding to make it compulsory for the firms to acquire sustainability 
in their business model $[4,9,77]$. Table 4 explores the key studies discussing I4.0 and its impact on CE in detail.

The optimisation of products and services to achieve a functional service economy helps create more excellent value for an extended period [108,109]. In support of this perception, [110] put forward effective strategies for maintaining a sustainable business system that includes product as a service (PaaS), infrastructure building, IoT, energy recovery, and waste recovery as the crucial elements for I4.0 [45,91,111].

Therefore, various authors have assessed the correlation among these two most essential paradigms from several perspectives [51,112]. The majority of the papers used a broader view for analysis such as regeneration of the used product or using its component as a by-product for a new product $[17,113]$; rethinking the BM $[4,28,77,114]$; reducing the usage of virgin resources $[115,116]$ and enhancing efficiency $[17,21]$; reusing the used product by outsourcing [108]; repairing and maintenance of a defected product [117]; refurbishing and restoring by upgrading it [77]; remanufacturing, i.e., using a component of the discarded product in a new product with the same functionality [17,33]; repurposing a redundant product with a different functionality [4], and recycling of products or material [102].

Few authors have discussed this association by assessing this affiliation on a microlevel such as: life-cycle management $[9,106,113,118,119]$, supply-chain management $[69,78,115]$, value chain $[36,85,115,120]$, and stakeholders perception [86,121].

Table 4. Key studies in the research domain discussing how I4.0 and its technologies enable CE and vice versa.

\begin{tabular}{|c|c|c|c|c|c|c|c|c|c|c|c|c|c|c|c|}
\hline I4.0 and CE References & 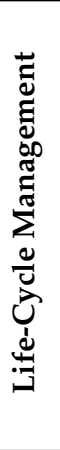 & 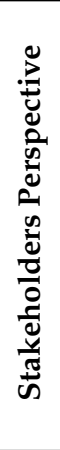 & 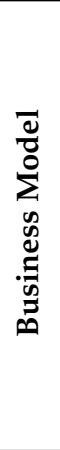 & 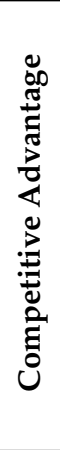 & 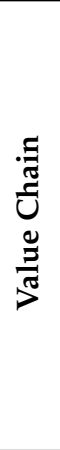 & 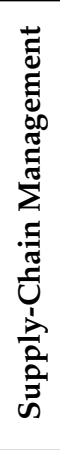 & 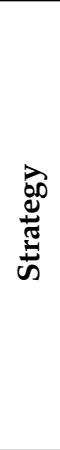 & 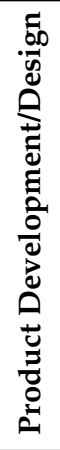 & 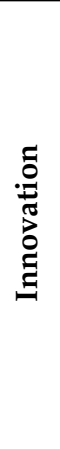 & 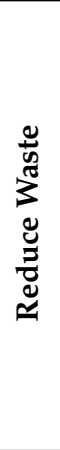 & 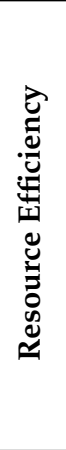 & $\begin{array}{l}\stackrel{0}{\tilde{U}} \\
\stackrel{0}{\approx}\end{array}$ & 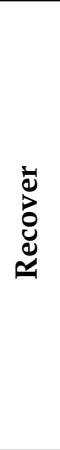 & $\underset{\mathscr{D}}{\mathscr{\varpi}}$ & 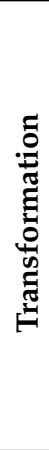 \\
\hline [9] & $x$ & & & & & $x$ & & & $x$ & & & $x$ & & & \\
\hline [14] & & & $x$ & & $x$ & & & & & & & & & & \\
\hline [16] & & & $x$ & & & $x$ & $x$ & & $x$ & & & & & & \\
\hline [36] & & & $x$ & & $x$ & & & & $x$ & & & & & & \\
\hline [49] & & & & & $\mathrm{x}$ & & & & $\mathrm{x}$ & & & & & & \\
\hline [52] & & & & & & & & & & & & $x$ & $x$ & $x$ & \\
\hline [69] & & & $\mathrm{x}$ & & & $x$ & & $x$ & & & & & & & $x$ \\
\hline [75] & & & & & & & & & & & & $\mathrm{x}$ & & & \\
\hline [79] & & & & & & & $x$ & & & & & & $x$ & & \\
\hline [111] & & & & & $x$ & & $x$ & & & & & & & & \\
\hline [119] & $x$ & $x$ & $x$ & & $\mathrm{x}$ & $x$ & & $x$ & & & & & $x$ & & $\mathrm{x}$ \\
\hline [121] & & $x$ & & & & & & & & $x$ & & & $x$ & & \\
\hline [122] & & & & & & $x$ & $x$ & & & & & & & & \\
\hline [123] & & & & & & $\mathrm{x}$ & & & & & & & & & \\
\hline [124] & & & & & $\mathrm{x}$ & $\mathrm{x}$ & $x$ & & & & & & & & \\
\hline
\end{tabular}

\subsubsection{Linking Servitisation and CE}

The study indicates that servitisation and CE mainly emphasise servitisation as a critical driver for resource reduction $[43,100,125,126]$. Manufacturers and users regularly take decisions related to elevating and investing capital in the industry $[43,100,125,126]$. 
These decisions are critically based on a significant number of factors from across the globe [127]. Servitisation literature follows a similar trend to that of I4.0 and CE. Several papers used for analysing this correlation perceive CE as a vital idea that significantly contributes to servitisation through increased product longevity [55,61], closed-loop supply chains [128], and resource and functional efficiency [58], as discussed in Table 5.

Rymaszewska [1] explains that the flaring of the operations of businesses via multistakeholder partnerships $[13,55,64,66]$ can help the organisations gain competitive advantages [13], creating more efficient supply-chain systems [51,61,88,128], and limiting costs $[2,106,112]$ by sharing digital solutions among related stakeholders. Bressanelli et al. [4] suggested a circular economic BM is a primary reason affecting how organisations manufacture, collect and produce value within closed-loop resources [40,51,60,61,64,87]. It is hypothesised as maintenance, repair redistribution (reuse without treatment), disposal, recycling, remanufacturing, energy recovery, and upgrading [67,129].

In most papers, researchers have identified that the CE concept extends the product life cycle and that servitisation is the system that facilitates this transition along with the entire lifespan $[58,60,61,70,77]$. The redesigning of operations has been studied widely in industries such as those relating to textiles [129], architecture [112], clothing [130], etc., where few authors have discussed servitisation as a solution for decreasing environmental risks $[43,90,131]$. Similarly, the product life extension model is used for recapturing the potential circular value of the manufacture of goods $[13,17,64]$.

Few authors highlight the sharing platform model as another circular model that links products with those who want them [33,40]. It is used when organisations keep their products in the market for as long as possible [132]. This discourse with the CE principles, where the goods' history is considered an arrangement of trajectories instead of a liner path design for the production, consumption, and disposal stages [40,106].

Table 5. Key studies in the research domain discussing how servitisation enables CE and vice versa.

\begin{tabular}{|c|c|c|c|c|c|c|c|c|c|c|c|c|c|c|}
\hline $\begin{array}{l}\text { Servitisation and CE } \\
\text { References }\end{array}$ & 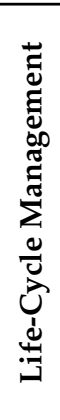 & 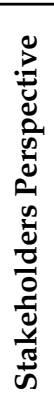 & 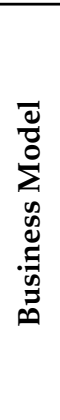 & 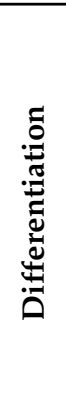 & 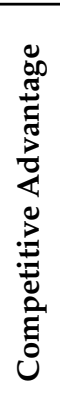 & 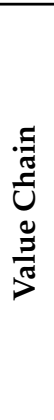 & 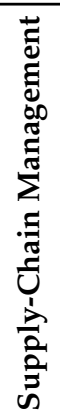 & 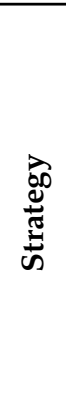 & 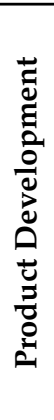 & 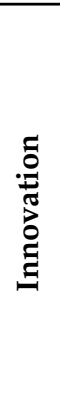 & 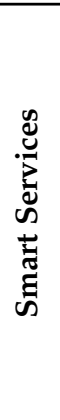 & 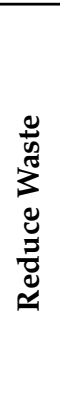 & 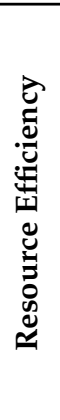 & 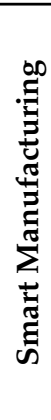 \\
\hline [13] & & $x$ & & $x$ & $x$ & $x$ & & & & & & & & \\
\hline [40] & & & & & & & & $x$ & & $x$ & $x$ & & & $x$ \\
\hline [55] & & $x$ & & & & $x$ & & $x$ & & & & & & \\
\hline [58] & $x$ & & & & & & & & $x$ & & & & & $x$ \\
\hline [60] & & & $x$ & & & $x$ & & & & & & & & \\
\hline [64] & & $x$ & $x$ & & & $x$ & & & & & $x$ & & & \\
\hline [66] & & $x$ & $x$ & & & & & & & & $x$ & & & $x$ \\
\hline [70] & $x$ & & & & & $x$ & & & $x$ & & & & $x$ & $x$ \\
\hline [77] & $x$ & & & & & $x$ & & & $x$ & & & & $x$ & $x$ \\
\hline [133] & & & $x$ & & & & & & & $x$ & & & & \\
\hline [87] & & & $x$ & & & & & & & & $x$ & & & \\
\hline [88] & & & & & & & $x$ & $x$ & & & & & & \\
\hline [134] & & & $x$ & & & $x$ & $x$ & & & $x$ & & & & \\
\hline [129] & & & & & & & & $x$ & & & & $x$ & $x$ & \\
\hline [132] & & & $x$ & & & $x$ & & & & $x$ & & & & \\
\hline
\end{tabular}




\subsection{Impact on the Firm's Performance}

I4.0, CE, and servitisation critically impact a firm's performance by increasing production efficiency and significantly contributing to business systems effectiveness $[17,70,77,90,135]$. The IoT and other innovative technologies help complement product life-cycle approaches [80,82], enabling the efficient incorporation of product-related information from the formulation of ideas towards describing the products, evaluating the businesses cases, product design and solution, and product improvements [13].

Similarly, with digitisation and servitisation, companies can integrate digital technologies for production and consumer management [80]. In simple terms, I4.0 is playing a significant role in supporting and preserving future global competitiveness [8]. On the other hand, due to the uncertainty in IoT's implications and actual effects, there are still contradictory proclamations related to its potential risks and benefits from practitioners, politicians, researchers, and consultants $[17,65,80]$.

A cost management assessment of this relationship is pivotal in justifying a firm's operational and capital expenditure during and after the transition phase [80]. Cost management mainly focuses on three significant areas: impact on the revenue stream, growth, and profitability. A brief description of financial measures is used to assess a firm's economic performance $[136,137]$.

After careful consideration, the authors identified that numerous papers focused on investigating the redesigning of the operational stream of a firm, variations in operational efficacy [132], or disparities in operational performance after the transformation of a firm. In contrast, some have broadly presented the idea of assessing financial arrangements [72,105]. However, none have provided any concrete evidence of economic parameters [138]. Moreover, the authors rarely evaluated the performance of firms from a legal or regulatory perspective [84].

Therefore, Table 6 highlights the studies according to the metrics or parameters that the authors used to investigate the performance of service-centric firms when they adopted a CE with I4.0 technologies. A brief explanation about the operational and financial performance indicators is given below:

- Operational Performance

- Financial Performance

\subsubsection{Operational Performance}

Businesses based on servitisation will embrace this transition towards the fourth industrial revolution combined with sustainability through the CE in different ways [45,77,91]. I4.0 technologies are mostly data-driven analytics that provides a greater level of flexibility [93]. Thus, firms that adopt the CE will capitalise through servitisation collectively with a higher degree of automation [9]. However, this road is paved with barriers [35]. There are three main domains: (i) Manufacturing operations: this includes asset management [128], smart manufacturing [111,139], end-to-end transparency [77], performance optimization [3,140], and human resource management; (ii) Maintenance and production asset management: involving the tracking and tracing of assets to ensure high quality, enhanced functionality/performance, and to monitor the degradation of assets [6,109]; (iii) Field services: these are value-added services such as installation, maintenance, and repairs $[1,42,63]$. Therefore, a radical shift in BM will serve as the capable connection between service design and a circular product $[77,114,140]$ through streamlined data sharing among stakeholders $[4,114]$.

The management principles from the BM perspective have been vaguely studied across different domains [141]. It is believed that the combination of I4.0, CE, and servitisation will create an entirely new manufacturing concept. Therefore, an overview of the main trends concerning the themes and expected development in the literature of key variables (I4.0, servitisation, and CE) is provided as follow: 


\section{- $\quad$ Business Model}

BM has always been a vital pillar in management sciences [40]. To cater to global competitions, businesses are bound to adopt an efficient and adaptable BM [61,114,142,143] to deliver a high level of flexibility and transparency in developing, designing, and manufacturing high-quality products and service packages at an affordable price [70,117].

I4.0 will support creating value by reducing operating costs through end-to-end integration [144]. At the same time, servitisation increases the efficiency of remanufacturing, reusing, and recycling systems due to analytical algorithms that process big data collected at different stages of production [135,142]. It is a dual-dimensional, conceptual representation of a firm's value creation and value capturing profitably and sustainably $[35,141]$. Another essential value domain of a BM is its value propositions, which answer the question as to why customers prefer the firm over other businesses operating in the market. Studying this shift would aid in identifying the potential prospects in the combined BM from the firm's perspective.

- Value Domain

The diversification of the traditional $\mathrm{BM}$ has become a radical measure in reconfiguring value networks [85]. Businesses opt for superior value propositions to integrate effective and efficient functionalities to a circular product [115]. These value propositions are interconnected elements of a BM [128] that help a firm to gain a competitive advantage in the market [145]. The traditional value domain was majorly concerned with the creation of value through financial measures $[100,146]$. It is now adding value-capturing and value opportunities to help a firm survive in the market [77,92].

The revised value drivers emphasise increasing resource efficiency, reducing material consumption $[70,71,87]$, extending the lifespan of a product with enhanced residual value $[23,67,83,147]$, and closing the loop $[41,103,148]$. I4.0 technologies (IoT, big data and analytics, cloud computing, and robots) are playing a vital role in improving product design $[35,65,121]$, attracting new customers while upholding the existent customer segments $[12,71,149]$ by providing add-on technical and maintenance support $[44,150,151]$. Several authors noted that servitisation would benefit firms operating in any sector if they reconfigure their BM by integrating I4.0 technologies [9,14,61,133,152-155].

- Supply Chain Management

Supply Chain Management (SCM) plays a critical role in enabling a firm's competitiveness $[117,156]$. Therefore, in today's global dynamic market, businesses must rethink their SC to survive in the market $[1,117]$. SC manages the association of services offered by independent firms at different stages (production, logistics, and sales), resulting in transparency and flexibility provided by I4.0-enabled digitalisation [37]. SCM helps a firm measure and monitor the performance parameters that establish a benchmark to regulate value-added operations [46]. Therefore, it has become a vital task for firms to identify and infuse innovative, sustainable, and cost-effective resolutions into their supply-chain network [152].

Ramsheva et al. [88] suggested this reconfiguration of the system calls for expansion and collaboration across the entire supply-chain network to make it resilient and less wasteful. This SLR identifies a need for measuring the value of I4.0 technologies and their ability to mitigate the technical, economic, compliance, and logistical challenges. The results of this study indicate that I4.0 will provide strategic oversight on a product's sustainability and functional efficacy that can be shared across a firm's supply-chain network [93].

\subsubsection{Financial Performance}

$\mathrm{CE}$ has become a well-established global concern for sustainable production and consumption. Meanwhile, the role of I4.0 technologies in this transformation is expected to be profound. Therefore, it is vital to ensure the $\mathrm{CE}$ delivers on its sustainability promises. For that purpose, the management of a firm needs to assess its viability and anticipate 
the impact of $\mathrm{CE}$ adoption within their BM while offering servitisation with the help of I4.0 technologies.

The impact of the key variables (I4.0, CE, and servitisation) on the revenue stream, financial performance, and growth in the market is described in detail in the next section.

- Impact on Revenue stream

Cash-flow management gives an idea of changes that occur in business accounts $[157,158]$. It includes cash and cash equivalents representing the costs associated with operations, investment, and financing activities. Revenues/income from trading can be calculated using income generating ratios such as return on asset (ROA), return on equity (ROE), and return on investment (ROI) [98,159].

The studies used in this SLR often point out that the transformation of a firm from linear to circular is imposed in different phases. Therefore, following the directives presented by the Ellen MacArthur Foundation, firms are suggested to review their revenue stream as the profits might differ in the short and long term $[82,87]$.

A common perception of the circular product in the manufacturing sector is its positive impact on the revenue stream $[72,88,107]$. Businesses are incentivised to engineer products to enhance their durability [101]. It is evident from Table 6 that researchers are determined to investigate the operational and financial efficacy of this increasing trend where businesses are utilising I4.0 technologies to make their resources stay in the cycle for as long as possible and deliver efficient and practical functionality to the customer [115].

Thus, as businesses are incentivised to engineer products with enhanced durability [103], their ROA will differ depending on their payback period [160]. Meanwhile, Chang et al. [44] and Cainelli et al. [139] suggested that a higher revenue stream is contingent on market share. Weking et al. [14] also advocate that firms will capture a higher customer base that will translate into a higher rate of return when firms serve larger market [44,127]; by offering distinctive and customised products [83] along with value-added services $[23,34,150]$

- Impact on Growth

Organisations are reliant on withholding investment flows [108]. Their growth is determined by standard features (size and age) and obligations, future growth prospects, and innovation [161]. The development of a business largely depends upon acquiring assets and the provision to finance them [162].

Limited studies have assessed the legal and regulatory policies and performance connected with the key variables (I4.0, servitisation, and CE). The desire for growth is one of the vital drivers for organisations, along with underlying motivations such as internal drivers that depend on the leadership strengths like an organisation's culture, the capability to change, and identifying opportunities [80,104,110,129,133,134,136,137,161]. However, it is not clear from the analysis of the finalised papers what legal risks may occur during any transformation, how companies will manage them, or how they will affect a firm's performance.

Then there are external enablers, and organisations are expected to invest financial and human resources into predicting changing trends and opportunities in the market $[138,146]$. Few authors have mentioned the guidelines and regulations imposed in different countries, but there is no explanation about their management or jeopardies. Hence, by critically reviewing the extensive scientific papers, the authors tried to understand the variations in the market. This can be through a technology development (I4.0) or sustainability paradigm (CE) that will help firms to gain a competitive advantage $[160,163]$ in the market $[73,164]$.

A cross-national study investigating the difference in policymaking between the Taiwanese and Chinese markets concentrated on the "political and legal" aspect of environmental policies [84]. In this context, government influence and laws and regulations play a vital role in how I4.0 technologies favour the transition towards servitisation while adopting the CE paradigm [115]. 


\section{- Impact on Profitability}

Another important instrument is the profitability of a business that generates working capital [137]. Existing literature suggested various indicators that are positively associated with innovation in a firm [163], such as shared sustainable goals [165], development and redesigning processes and operations $[164,166]$, and addition of service-package element with products [167].

Demirel [101] recommended businesses invest in capital (human and physical), opting for innovation (advancement in product and processes through R\&D) [126,136] and market expansion [88]. Hence, this study envisages a shift from the drivers and opportunities associated with I4.0. It leverages $\mathrm{CE}$ and servitisation by reviewing existing studies on these topics to identify challenges, barriers, and strategies to eliminate adverse effects. In particular, a lack of research was found regarding the investigation of the impact on a firm's profitability in both the short and long term during and after their transition journey $[98,99,168,169]$.

Table 6. Key studies in the research domain discussing how I4.0, servitisation, and CE affect a firm's performance.

\begin{tabular}{|c|c|c|c|c|c|c|}
\hline $\begin{array}{c}\text { Impact on Firm's } \\
\text { Performance } \\
\text { References }\end{array}$ & $\begin{array}{l}\text { Main Variables } \\
\text { Used in the Study }\end{array}$ & $\begin{array}{c}\text { Financial } \\
\text { Performance }\end{array}$ & $\begin{array}{l}\text { Operational } \\
\text { Performance }\end{array}$ & $\begin{array}{c}\text { Legal/Regulatory } \\
\text { Policies }\end{array}$ & $\begin{array}{c}\text { Environmental } \\
\text { Performance }\end{array}$ & $\begin{array}{c}\text { Social } \\
\text { Performance }\end{array}$ \\
\hline$[1]$ & Servitisation+I4.0 & & $x$ & $x$ & & \\
\hline [10] & Servitisation+I4.0 & & $x$ & & & $x$ \\
\hline [14] & $\mathrm{CE}+\mathrm{I} 4.0$ & $x$ & & & & \\
\hline [21] & $\mathrm{CE}+\mathrm{I} 4.0$ & & $x$ & & & \\
\hline [40] & Servitisation $+\mathrm{I} 4.0+\mathrm{CE}$ & & $\mathrm{x}$ & & $x$ & \\
\hline [49] & Servitisation+I4.0 & & $x$ & & & \\
\hline$[52]$ & $\mathrm{CE}+\mathrm{I} 4.0$ & & $x$ & & & \\
\hline [61] & Servitisation+CE & & & & $x$ & $x$ \\
\hline$[62]$ & Servitisation+I4.0 & & $x$ & & & \\
\hline$[65]$ & Servitisation $+\mathrm{I} 4.0+\mathrm{CE}$ & $x$ & $x$ & & & \\
\hline [77] & Servitisation+I4.0+CE & & $x$ & & & \\
\hline$[78]$ & $\mathrm{CE}+\mathrm{I} 4.0$ & $x$ & & & & \\
\hline [170] & $\mathrm{CE}+\mathrm{I} 4.0$ & $x$ & & & & \\
\hline$[88]$ & Servitisation+CE & $x$ & & & $x$ & \\
\hline$[122]$ & $\mathrm{CE}+\mathrm{I} 4.0$ & $\mathrm{x}$ & $x$ & & & \\
\hline [165] & $\mathrm{CE}+\mathrm{I} 4.0$ & $\mathrm{x}$ & $\mathrm{x}$ & & $x$ & \\
\hline [139] & $\mathrm{CE}+\mathrm{I} 4.0$ & $x$ & $x$ & & $x$ & \\
\hline [129] & Servitisation $+\mathrm{CE}$ & & $x$ & & & $x$ \\
\hline [171] & $\mathrm{CE}+\mathrm{I} 4.0$ & & $x$ & & $x$ & \\
\hline [172] & $\mathrm{CE}+\mathrm{I} 4.0$ & $x$ & & & & \\
\hline
\end{tabular}

The results of this SLR demonstrate that BMs and value domains often associated with innovation are the most common assessment approaches. It is further observed that more comprehensive environmental assessments are presented in CE-related publications. In contrast, servitisation literature stresses operational and financial performance indicators [140]. Superficially, the legal and regulatory performance indicator is the least assessed. Hence, it is evident in Table 6 that a comprehensive assessment including financial, operational, economic, social, and legal performance indicators from the potential of BM perspective has rarely been tested in the existing body of I4.0, CE, and servitisation literature.

\section{Conclusions and Future Recommendations}

This research conceptualised the various dimensions of I4.0, servitisation, and CE through a rigorous SLR. This study developed an assessment to examine the relationships between critical variables based on 139 accredited scientific papers. The analysis process 
consisted of three steps. The first section deepened the understanding of $\mathrm{CE}$ and the servitisation standpoint and investigated how I4.0 technologies impact the BM and service systems $[42,63,153]$. This study addresses the role of I4.0 in servitisation and CE, and aligns $\mathrm{BM}$, value propositions, and financial performance indicators. The second step integrated thematic categories to assess correlations; while the third step investigated the impact of this collaboration on a firm's performance. The main contributions of this research can be summarised as:

- This SLR has offered a thorough review from the business and management context to provide a deeper insight into how well I4.0 supports CE and servitisation. Since I4.0, servitisation and CE have become the most debated topics [9] in the last decade. This study provides a comprehensive review of servitisation that led to a more circular supply chain [113] from the perspective of the firms and indicated what role I4.0 played in enabling this transformation $[85,93,173]$.

- It is evident from the analysis presented in this study that majority of the authors agree that firms should systematically adopt I4.0 technologies as they support CE to create value through servitisation. However, there is still a lack of practical implications to validate theoretical knowledge $[9,55,85,174]$. Thus, more empirical evidence is required regarding the reconfiguration of the BM $[12,56,104]$, principally in terms of capturing the value through innovation $[58,65,98,107]$, setting the strategy based on circularity $[80,101,133]$, offering smart-product through smart-services, and managing the supply-chain network $[38,124]$.

- Businesses are frequently pushed to experiment with innovative BMs [56] to capture unique value propositions while curbing operational costs $[10,14,15,109]$. The trend from the analysis of this study reveals that most of the servitisation literature discusses this from a functional perspective (see Table 6) $[14,56]$. Servitisation is seen as a path that enhances the downstream opportunities by providing autonomous services to their customers $[1,62]$

- This study adds to current knowledge since it assesses that I4.0 can play in solidifying the sustainable global competitiveness of a firm [16] through servitisation $[9,75]$. Hence, there is a need for future researchers to investigate factors that will enable firms to take advantage of the opportunities which accompany I4.0 and project strategies to overcome the barriers associated with this transition [52,86,151].

- This study suggests that many uncertainties and risks occur during the transformation phase $[1,55]$. To eradicate these uncertainties, [119], we propose four methods that can transform these challenges into opportunities, i.e., the reconfiguration of the revenue model, external environment, customer relationship, and the optimising of cost structures. The journal papers used for this analysis are mostly literature reviews or case-studies. Thus, generalisation is challenging to achieve. Consequently, future researchers are instructed to conduct a longitudinal investigation using a mixedmethod approach to run a detailed assessment of this venture's financial, economic, and social aspects $[12,40,44,106]$.

- The finding of this SLR indicates that the relationship between the key variables of this study is expected to impact firms' performance [96] positively. Adopting I4.0 technologies to business and manufacturing models enables sustainability, energy, and resource efficiency while enhancing performance efficacy and offering smart products through smart services. This integration will eventually lead to a market shift $[32,41,89]$ with enhanced management and production capability $[12,64,71,157]$. Therefore, perspective presented in this study can be used as a baseline by future researchers to investigate the hidden gems in this venture and explore innovative strategies from its integration. This paper presented the literature that focuses on large enterprises from developed countries using generic CE practices. Therefore, future research is recommended to investigate the impact of a specific I4.0 technology when firms adopt servitisation BMs surrounding an explicit CE practice. 
Author Contributions: Conceptualization, S.A. (Sehrish Atif), S.A. (Shehzad Ahmed); methodology, S.A. (Shehzad Ahmed), S.A. (Sehrish Atif); validation, B.Z., M.W., Z.P.; formal analysis, S.A. (Shehzad Ahmed), M.W., S.A. (Sehrish Atif); investigation, B.Z., S.A. (Sehrish Atif), M.W.; resources, Z.P., S.A. (Shehzad Ahmed); data curation, Z.P., S.A. (Sehrish Atif); writing-original draft preparation, S.A. (Sehrish Atif), S.A. (Shehzad Ahmed); visualization, M.W., B.Z., S.A. (Shehzad Ahmed); supervision, S.A. (Shehzad Ahmed), L.Q.; project administration, L.Q., S.A. (Shehzad Ahmed). All authors have read and agreed to the published version of the manuscript.

Funding: This research received no external funding.

Institutional Review Board Statement: Not applicable.

Informed Consent Statement: Not applicable.

Data Availability Statement: Not applicable.

Conflicts of Interest: The authors declare no conflict of interest.

\section{References}

1. Rymaszewska, A.; Helo, P.; Gunasekaran, A. IoT powered servitization of manufacturing-An exploratory case study. Int. J. Prod. Econ. 2017, 192, 92-105. [CrossRef]

2. Kohtamäki, M.; Parida, V.; Oghazi, P.; Gebauer, H.; Baines, T. Digital servitization business models in ecosystems: A theory of the firm. J. Bus. Res. 2019, 104, 380-392. [CrossRef]

3. Majeed, A.; Zhang, Y.; Ren, S.; Lv, J.; Peng, T.; Waqar, S.; Yin, E. A big data-driven framework for sustainable and smart additive manufacturing. Robot. Comput. Integr. Manuf. 2021, 67, 102026. [CrossRef]

4. Bressanelli, G.; Adrodegari, F.; Perona, M.; Saccani, N. The role of digital technologies to overcome Circular Economy challenges in PSS Business Models: An exploratory case study. Procedia CIRP 2018, 73, 216-221. [CrossRef]

5. Schröder, P.; Lemille, A.; Desmond, P. Making the circular economy work for human development. Resour. Conserv. Recycl. 2020, 156, 104686. [CrossRef]

6. Kiel, D.; Arnold, C.; Voigt, K.-I. The influence of the Industrial Internet of Things on business models of established manufacturing companies-A business-level perspective. Technovation 2017, 68, 4-19. [CrossRef]

7. Davies, I.A.; Doherty, B. Balancing a Hybrid Business Model: The Search for Equilibrium at Cafédirect. J. Bus. Ethics 2018, 157, 1043-1066. [CrossRef]

8. Rosa, P.; Sassanelli, C.; Urbinati, A.; Chiaroni, D.; Terzi, S. Assessing relations between Circular Economy and Industry 4.0: A systematic literature review. Int. J. Prod. Res. 2019, 58, 1662-1687. [CrossRef]

9. Shihundla, T.B.; Mpofu, K.; Adenuga, O.T. Integrating Product-Service Systems into the manufacturing industry: Industry 4.0 perspectives. Procedia CIRP 2019, 83, 8-13. [CrossRef]

10. Schroeder, P.; Anggraeni, K.; Weber, U. The Relevance of Circular Economy Practices to the Sustainable Development Goals. J. Ind. Ecol. 2019, 23, 77-95. [CrossRef]

11. Kohtamäki, M.; Parida, V.; Patel, P.C.; Gebauer, H. The relationship between digitalization and servitization: The role of servitization in capturing the financial potential of digitalization. Technol. Forecast. Soc. Chang. 2020, 151, 119804. [CrossRef]

12. Lightfoot, H.; Baines, T.S.; Smart, P. The servitization of manufacturing. Int. J. Oper. Prod. Manag. 2013, 33, 1408-1434. [CrossRef]

13. Rehman, M.H.U.; Chang, V.; Batool, A.; Wah, T.Y. Big data reduction framework for value creation in sustainable enterprises. Int. J. Inf. Manag. 2016, 36, 917-928. [CrossRef]

14. Dev, N.K.; Shankar, R.; Qaiser, F.H. Industry 4.0 and circular economy: Operational excellence for sustainable reverse supply chain performance. Resour. Conserv. Recycl. 2020, 153, 104583. [CrossRef]

15. Weking, J.; Stöcker, M.; Kowalkiewicz, M.; Böhm, M.; Krcmar, H. Leveraging industry 4.0—A business model pattern framework. Int. J. Prod. Econ. 2020, 225, 107588. [CrossRef]

16. Lieder, M.; Asif, F.M.A.; Rashid, A.; Mihelič, A.; Kotnik, S. Towards circular economy implementation in manufacturing systems using a multi-method simulation approach to link design and business strategy. Int. J. Adv. Manuf. Technol. 2017, 93, 1953-1970. [CrossRef]

17. Santamaría, L.; Nieto, M.J.; Miles, I. Service innovation in manufacturing firms: Evidence from Spain. Technovation 2012, 32, 144-155. [CrossRef]

18. Vaidya, S.; Ambad, P.; Bhosle, S. Industry 4.0—A Glimpse. Procedia Manuf. 2018, 20, 233-238. [CrossRef]

19. Stock, T.; Obenaus, M.; Kunz, S.; Kohl, H. Industry 4.0 as enabler for a sustainable development: A qualitative assessment of its ecological and social potential. Process. Saf. Environ. Prot. 2018, 118, 254-267. [CrossRef]

20. Neely, A. Exploring the financial consequences of the servitization of manufacturing. Oper. Manag. Res. 2008, 1, 103-118. [CrossRef]

21. Romero, D.; Rossi, M. Towards Circular Lean Product-Service Systems. Procedia CIRP 2017, 64, 13-18. [CrossRef]

22. Tranfield, D.; Denyer, D.; Smart, P. Towards a Methodology for Developing Evidence-Informed Management Knowledge by Means of Systematic Review. Br. J. Manag. 2003, 14, 207-222. [CrossRef] 
23. Kunisch, S.; Menz, M.; Bartunek, J.M.; Cardinal, L.B.; Denyer, D. Feature Topic at Organizational Research Methods. Organ. Res. Methods 2018, 21, 519-523. [CrossRef]

24. Kitchenham, B.; Brereton, O.P.; Budgen, D.; Turner, M.; Bailey, J.; Linkman, S. Systematic literature reviews in software engineering-A systematic literature review. Inf. Softw. Technol. 2009, 51, 7-15. [CrossRef]

25. Fisch, C.; Block, J. Six tips for your (systematic) literature review in business and management research. Manag. Rev. Q. 2018, 68, 103-106. [CrossRef]

26. Okorie, O.; Salonitis, K.; Charnley, F.; Moreno, M.; Turner, C.; Tiwari, A. Digitisation and the Circular Economy: A Review of Current Research and Future Trends. Energies 2018, 11, 3009. [CrossRef]

27. Anastasiades, K.; Blom, J.; Buyle, M.; Audenaert, A. Translating the circular economy to bridge construction: Lessons learnt from a critical literature review. Renew. Sustain. Energy Rev. 2020, 117, 109522. [CrossRef]

28. Agrawal, V.; Atasu, A.; Ülkü, S. Leasing, Modularity, and the Circular Economy. Manag. Sci. 2021. [CrossRef]

29. Demirkan, H.; Bess, C.; Spohrer, J.; Rayes, A.; Allen, D.; Moghaddam, Y. Innovations with smart service systems: Analytics, big data, cognitive assistance, and the internet of everything. Commun. Assoc. Inf. Syst. 2015, 37, 35. [CrossRef]

30. Mourtzis, D.; Zervas, E.; Boli, N.; Pittaro, P. A cloud-based resource planning tool for the production and installation of industrial product service systems (IPSS). Int. J. Adv. Manuf. Technol. 2020, 106, 4945-4963. [CrossRef]

31. Camacho-Otero, J.; Boks, C.; Pettersen, I.N. Consumption in the Circular Economy: A Literature Review. Sustainability 2018, 10, 2758. [CrossRef]

32. Frank, A.G.; Mendes, G.; Ayala, N.F.; Ghezzi, A. Servitization and Industry 4.0 convergence in the digital transformation of product firms: A business model innovation perspective. Technol. Forecast. Soc. Chang. 2019, 141, 341-351. [CrossRef]

33. Matthyssens, P. Reconceptualizing value innovation for Industry 4.0 and the Industrial Internet of Things. J. Bus. Ind. Mark. 2019, 34, 1203-1209. [CrossRef]

34. Beier, G.; Niehoff, S.; Xue, B. More Sustainability in Industry through Industrial Internet of Things? Appl. Sci. 2018, 8, 219. [CrossRef]

35. Bag, S.; Pretorius, J.H.C. Relationships between industry 4.0, sustainable manufacturing and circular economy: Proposal of a research framework. Int. J. Organ. Anal. 2020. [CrossRef]

36. Sony, M. Design of cyber physical system architecture for industry 4.0 through lean six sigma: Conceptual foundations and research issues. Prod. Manuf. Res. 2020, 8, 158-181. [CrossRef]

37. Jabbour, C.J.C.; Fiorini, P.D.C.; Wong, C.W.; Jugend, D.; Jabbour, A.B.L.D.S.; Seles, B.M.R.P.; Pinheiro, M.A.P.; da Silva, H.M.R. First-mover firms in the transition towards the sharing economy in metallic natural resource-intensive industries: Implications for the circular economy and emerging industry 4.0 technologies. Resour. Policy 2020, 66, 101596. [CrossRef]

38. Manavalan, E.; Jayakrishna, K. A review of Internet of Things (IoT) embedded sustainable supply chain for industry 4.0 requirements. Comput. Ind. Eng. 2019, 127, 925-953. [CrossRef]

39. Martín, M.G.; Álvarez, A.P.; Ordieres-Meré, J.; Villalba-Díez, J.; Morales-Alonso, G. New Business Models from Prescriptive Maintenance Strategies Aligned with Sustainable Development Goals. Sustainability 2021, 13, 216. [CrossRef]

40. Stock, T.; Seliger, G. Opportunities of Sustainable Manufacturing in Industry 4.0. Procedia CIRP 2016, 40, 536-541. [CrossRef]

41. Bag, S.; Gupta, S.; Luo, Z. Examining the role of logistics 4.0 enabled dynamic capabilities on firm performance. Int. J. Logist. Manag. 2020, 31, 607-628. [CrossRef]

42. Rajput, S.; Singh, S.P. Industry 4.0-Challenges to implement circular economy. Benchmarking Int. J. 2021, 28, 1717-1739. [CrossRef]

43. Wang, G.; Gunasekaran, A.; Ngai, E.W.; Papadopoulos, T. Big data analytics in logistics and supply chain management: Certain investigations for research and applications. Int. J. Prod. Econ. 2016, 176, 98-110. [CrossRef]

44. Chang, W.; Ellinger, A.E.; Kim, K.K.; Franke, G.R. Supply chain integration and firm financial performance: A meta-analysis of positional advantage mediation and moderating factors. Eur. Manag. J. 2016, 34, 282-295. [CrossRef]

45. Pinheiro, M.A.P.; Seles, B.M.R.P.; Fiorini, P.D.C.; Jugend, D.; Jabbour, A.B.L.D.S.; Da Silva, H.M.R.; Latan, H. The role of new product development in underpinning the circular economy. A systematic review and integrative framework. Manag. Decis. 2019, 57, 840-862. [CrossRef]

46. Abdel-Basst, M.; Mohamed, R.; Elhoseny, M. A novel framework to evaluate innovation value proposition for smart productservice systems. Environ. Technol. Innov. 2020, 20, 101036. [CrossRef]

47. Peker, Y.K.; Rodriguez, X.; Ericsson, J.; Lee, S.J.; Perez, A.J. A Cost Analysis of Internet of Things Sensor Data Storage on Blockchain via Smart Contracts. Electronics 2020, 9, 244. [CrossRef]

48. Osterrieder, P.; Budde, L.; Friedli, T. The smart factory as a key construct of industry 4.0: A systematic literature review. Int. J. Prod. Econ. 2020, 221, 107476. [CrossRef]

49. Bag, S.; Gupta, S.; Kumar, S. Industry 4.0 adoption and 10R advance manufacturing capabilities for sustainable development. Int J. Prod. Econ. 2021, 231, 107844. [CrossRef]

50. Li, A.Q.; Found, P. Towards sustainability: PSS, digital technology and value co-creation. In Proceedings of the 9th CIRP IPSS Conference: Circular Perspectives on PSS, Copenhagen, Denmark, 19-21 June 2017; pp. 79-84.

51. Tukker, A. Product services for a resource-efficient and circular economy-A review. J. Clean. Prod. 2015, 97, 76-91. [CrossRef]

52. Reim, W.; Parida, V.; Sjödin, D.R. Risk management for product-service system operation. Int. J. Oper. Prod. Manag. 2016, 36, 665-686. [CrossRef] 
53. Adel, R.; Wiesner, S.A. Conceptual approach for value driven performance in servitising companies. Int. J. Serv. Oper. Manag. 2015, 21, 504-531. [CrossRef]

54. Teece, D.J.; Pisano, G.; Shuen, A. Dynamic Capabilities and Strategic Management. Strateg. Manag. J. 1998, 18, 509-533. [CrossRef]

55. Witell, L.; Snyder, H.; Gustafsson, A.; Fombelle, P.; Kristensson, P. Defining service innovation: A review and synthesis. J. Bus. Res. 2016, 69, 2863-2872. [CrossRef]

56. Pakurár, M.; Haddad, H.; Nagy, J.; Popp, J.; Oláh, J. The Service Quality Dimensions that Affect Customer Satisfaction in the Jordanian Banking Sector. Sustainability 2019, 11, 1113. [CrossRef]

57. Mathieu, V. Product services: From a service supporting the product to a service supporting the client. J. Bus. Ind. Mark. 2001, 16, 39-61. [CrossRef]

58. Kühl, C.; Bourlakis, M.; Aktas, E.; Skipworth, H. How does servitisation affect supply chain circularity?-A systematic literature review. J. Enterp. Inf. Manag. 2019, 33, 703-728. [CrossRef]

59. Leite, A.F.D.M.; Canciglieri, M.B.; Goh, Y.M.; Monfared, R.P.; Loures, E.D.F.R.; Canciglieri, O. Current Issues in the Flexibilization of Smart Product-Service Systems and their Impacts in Industry 4.0. Procedia Manuf. 2020, 51, 1153-1157. [CrossRef]

60. Frederiksen, T.; Pieroni, M.P.P.; Pigosso, D.; McAloone, T. Strategic Development of Product-Service Systems (PSS) through Archetype Assessment. Sustainability 2021, 13, 2592. [CrossRef]

61. Bustinza, O.F.; Gomes, E.; Vendrell-Herrero, F.; Baines, T. Product-service innovation and performance: The role of collaborative partnerships and R\&D intensity. RED Manag. 2019, 49, 33-45. [CrossRef]

62. Li, X.; Wang, Z.; Chen, C.-H.; Zheng, P. A data-driven reversible framework for achieving Sustainable Smart product-service systems. J. Clean. Prod. 2021, 279, 123618. [CrossRef]

63. Reim, W.; Sjödin, D.R.; Parida, V. Servitization of global service network actors-A contingency framework for matching challenges and strategies in service transition. J. Bus. Res. 2019, 104, 461-471. [CrossRef]

64. Ghisetti, C.; Montresor, S. On the adoption of circular economy practices by small and medium-size enterprises (SMEs): Does "financing-as-usual" still matter? J. Evol. Econ. 2019, 30, 559-586. [CrossRef]

65. Rossi, J.; Bianchini, A.; Guarnieri, P. Circular Economy Model Enhanced by Intelligent Assets from Industry 4.0: The Proposition of an Innovative Tool to Analyze Case Studies. Sustainability 2020, 12, 7147. [CrossRef]

66. Esmaeilian, B.; Sarkis, J.; Lewis, K.; Behdad, S. Blockchain for the future of sustainable supply chain management in Industry 4.0. Resour. Conserv. Recycl. 2020, 163, 105064. [CrossRef]

67. Kristensen, H.S.; Remmen, A. A framework for sustainable value propositions in product-service systems. J. Clean. Prod. 2019, 223, 25-35. [CrossRef]

68. Copani, G.; Behnam, S. Remanufacturing with upgrade PSS for new sustainable business models. CIRP J. Manuf. Sci. Technol. 2020, 29, 245-256. [CrossRef]

69. Jabbour, A.B.L.D.S.; Ndubisi, N.O.; Seles, B.M.R.P. Sustainable development in Asian manufacturing SMEs: Progress and directions. Int. J. Prod. Econ. 2020, 225, 107567. [CrossRef]

70. Kozlenkova, I.V.; Samaha, S.A.; Palmatier, R.W. Resource-based theory in marketing. J. Acad. Mark. Sci. 2014, 42, 1-21. [CrossRef]

71. Spanos, Y.E.; Lioukas, S. An examination into the causal logic of rent generation: Contrasting Porter's competitive strategy framework and the resource-based perspective. Strat. Manag. J. 2001, 22, 907-934. [CrossRef]

72. Chuang, S.-H.; Lin, H.-N. Co-creating e-service innovations: Theory, practice, and impact on firm performance. Int. J. Inf. Manag. 2015, 35, 277-291. [CrossRef]

73. Zancul, E.D.S.; Takey, S.M.; Barquet, A.P.B.; Kuwabara, L.H.; Miguel, P.A.C.; Rozenfeld, H. Business process support for IoT based product-service systems (PSS). Bus. Process. Manag. J. 2016, 22. [CrossRef]

74. Bressanelli, G.; Adrodegari, F.; Perona, M.; Saccani, N. Exploring How Usage-Focused Business Models Enable Circular Economy through Digital Technologies. Sustainability 2018, 10, 639. [CrossRef]

75. Bal, A.; Badurdeen, F. A Business Model to Implement Closed-loop Material Flow in IoT-enabled Environments. Procedia Manuf. 2019, 38, 1284-1291. [CrossRef]

76. Seddon, J.J.; Currie, W.L. A model for unpacking big data analytics in high-frequency trading. J. Bus. Res. 2017, 70, 300-307. [CrossRef]

77. Tavares-Lehmann, A.T.; Varum, C. Industry 4.0 and Sustainability: A Bibliometric Literature Review. Sustainability 2021, 13, 3493. [CrossRef]

78. Tuttokmaği, Ö.; Kaygusuz, A. Smart Grids and Industry 4.0. In 2018 International Conference on Artificial Intelligence and Data Processing (IDAP); IEEE: New York, NY, USA, 2018; pp. 1-6. [CrossRef]

79. Michelini, G.; Moraes, R.N.; Cunha, R.N.; Costa, J.M.; Ometto, A.R. From Linear to Circular Economy: PSS Conducting the Transition. Procedia CIRP 2017, 64, 2-6. [CrossRef]

80. Lyons, A.C.; Um, J.; Sharifi, H. Product variety, customisation and business process performance: A mixed-methods approach to understanding their relationships. Int. J. Prod. Econ. 2020, 221, 107469. [CrossRef]

81. Sousa-Zomer, T.; Miguel, P.C. Product-service Systems as a Promising Approach to Sustainability: Exploring the Sustainable Aspects of a PSS in Brazil. Procedia CIRP 2015, 30, 138-143. [CrossRef]

82. Machado, C.G.; Winroth, M.P.; Da Silva, E.H.D.R. Sustainable manufacturing in Industry 4.0: An emerging research agenda. Int. J. Prod. Res. 2020, 58, 1462-1484. [CrossRef] 
83. Lin, K.C.; Shyu, J.Z.; Ding, K. A Cross-Strait Comparison of Innovation Policy under Industry 4.0 and Sustainability Development Transition. Sustainability 2017, 9, 786. [CrossRef]

84. Ozkan-Ozen, Y.D.; Kazancoglu, Y.; Mangla, S.K. Synchronized Barriers for Circular Supply Chains In Industry 3.5/Industry 4.0 Transition For Sustainable Resource Management. Resour. Conserv. Recycl. 2020, 161, 104986. [CrossRef]

85. Hernandez, R.J. Sustainable Product-Service Systems and Circular Economies. Sustainability 2019, 11, 5383. [CrossRef]

86. Ramsheva, Y.; Moalem, R.; Milios, L. Realizing a Circular Concrete Industry in Denmark through an Integrated Product, Service and System Perspective. Sustainability 2020, 12, 9423. [CrossRef]

87. D'Agostin, A.; de Medeiros, J.F.; Vidor, G.; Zulpo, M.; Moretto, C.F. Drivers and barriers for the adoption of use-oriented product-service systems: A study with young consumers in medium and small cities. Sustain. Prod. Consum. 2020, 21, 92-103. [CrossRef]

88. Saberi, S.; Kouhizadeh, M.; Sarkis, J.; Shen, L. Blockchain technology and its relationships to sustainable supply chain management. Int. J. Prod. Res. 2019, 57, 2117-2135. [CrossRef]

89. Frank, A.G.; Dalenogare, L.S.; Ayala, N.F. Industry 4.0 technologies: Implementation patterns in manufacturing companies. Int. J. Prod. Econ. 2019, 210, 15-26. [CrossRef]

90. Sajjad, A.; Eweje, G.; Tappin, D. Sustainable Supply Chain Management: Motivators and Barriers. Bus. Strateg. Environ. 2015, 24, 643-655. [CrossRef]

91. Gangi, F.; Daniele, L.M.; Varrone, N. How do corporate environmental policy and corporate reputation affect risk-adjusted financial performance? Bus. Strat. Environ. 2020, 29, 1975-1991. [CrossRef]

92. Côrte-Real, N.; Ruivo, P.; Oliveira, T.; Popovič, A. Unlocking the drivers of big data analytics value in firms. J. Bus. Res. 2019, 97, 160-173. [CrossRef]

93. Shrivastava, M.; Tamvada, J.P. Which green matters for whom? Greening and firm performance across age and size distribution of firms. Small Bus. Econ. 2017, 52, 951-968. [CrossRef]

94. Da Costa Fernandes, S.; Martins, L.D.; Campese, C.; Rozenfeld, H. Representing the Value Proposition of Product-Service Systems (PSS) in a Value-Based Perspective. In Proceedings of the Design Society: International Conference on Engineering Design; Cambridge University Press: Cambridge, UK, 2019; pp. 3091-3100. [CrossRef]

95. Giner, B.; Merello, P.; Pardo, F. Assessing the impact of operating lease capitalization with dynamic Monte Carlo simulation. J. Bus. Res. 2019, 101, 836-845. [CrossRef]

96. Rangkuti, M.M. The Effect Of Intellectual Capital And Financial Performance on Firm Value With Return on Investment as a Modeling Variable In The Mining Industry Listed On Indonesia Stock Exchange. Int. J. Public Budg. Account. Financ. 2020, 2, 1-11.

97. Scheel, C.; Aguiñaga, E.; Bello, B. Decoupling Economic Development from the Consumption of Finite Resources Using Circular Economy. A Model for Developing Countries. Sustainability 2020, 12, 1291. [CrossRef]

98. Demirel, P.; Danisman, G.O. Eco-innovation and firm growth in the circular economy: Evidence from European small- and medium-sized enterprises. Bus. Strat. Environ. 2019, 28, 1608-1618. [CrossRef]

99. Sehnem, S.; Vazquez-Brust, D.; Pereira, S.C.F.; Campos, L.M. Circular economy: Benefits, impacts and overlapping. Supply Chain Manag. Int. J. 2019, 24, 784-804. [CrossRef]

100. Geissdoerfer, M.; Savaget, P.; Bocken, N.M.P.; Hultink, E.J. The Circular Economy-A new sustainability paradigm? J. Clean. Prod. 2017, 143, 757-768. [CrossRef]

101. Dalenogare, L.S.; Benitez, G.B.; Ayala, N.F.; Frank, A.G. The expected contribution of Industry 4.0 technologies for industrial performance. Int. J. Prod. Econ. 2018, 204, 383-394. [CrossRef]

102. Govindan, K.; Cheng, T.; Mishra, N.; Shukla, N. Big data analytics and application for logistics and supply chain management. Transp. Res. Part E Logist. Transp. Rev. 2018, 114, 343-349. [CrossRef]

103. Rizos, V.; Behrens, A.; Van Der Gaast, W.; Hofman, E.; Ioannou, A.; Kafyeke, T.; Flamos, A.; Rinaldi, R.; Papadelis, S.; Hirschnitz-Garbers, M.; et al. Implementation of Circular Economy Business Models by Small and Medium-Sized Enterprises (SMEs): Barriers and Enablers. Sustainability 2016, 8, 1212. [CrossRef]

104. Ormazabal, M.; Prieto-Sandoval, V.; Puga-Leal, R.; Jaca, C. Circular Economy in Spanish SMEs: Challenges and opportunities. J. Clean. Prod. 2018, 185, 157-167. [CrossRef]

105. Nakata, C.; Bahadir, S.C. Spotlight on design: Strengthening innovation for more product and service sales. J. Bus. Strat. 2020, 42, 83-90. [CrossRef]

106. Day, S. Drivers and Barriers to Product-Service System Consumer Adoption in a Fashion Subscription Case. Ph.D. Thesis, University of Warwick, Coventry, UK, 2019.

107. Bag, S.; Telukdarie, A.; Pretorius, J.; Gupta, S. Industry 4.0 and supply chain sustainability: Framework and future research directions. Benchmarking Int. J. 2018. [CrossRef]

108. D'Amato, D.; Veijonaho, S.; Toppinen, A. Towards sustainability? Forest-based circular bioeconomy business models in Finnish SMEs. For. Policy Econ. 2020, 110, 101848. [CrossRef]

109. Smeets, R. Circular Revenue Models in the Civil and Non-Residential Building Sector. An Investigation of Existing Barriers and the Influence of Product's Functional Lifecycle on Their Adoption. Master's Thesis, Utrecht University, Utrecht, The Netherlands, 2019.

110. Tseng, M.-L.; Chiu, A.S.; Liu, G.; Jantaralolica, T. Circular economy enables sustainable consumption and production in multi-level supply chain system. Resour. Conserv. Recycl. 2020, 154, 104601. [CrossRef] 
111. Werning, J.P.; Spinler, S. Transition to circular economy on firm level: Barrier identification and prioritization along the value chain. J. Clean. Prod. 2020, 245, 118609. [CrossRef]

112. Widmer, T. Assessing the Strengths and Limitations of Business Model Frameworks for Product Service Systems in the Circular Economy: Why Canvas and Co. Are Not Enough. Master's Thesis, Stockholm University, Stockholm, Sweden, 2016. [CrossRef]

113. Boer, D.; Segarra, M.; Fernández, A.I.; Vallès, M.; Mateu, C.; Cabeza, L.F. Approach for the analysis of TES technologies aiming towards a circular economy: Case study of building-like cubicles. Renew. Energy 2020, 150, 589-597. [CrossRef]

114. Lüdeke-Freund, F.; Gold, S.; Bocken, N.M.P. A Review and Typology of Circular Economy Business Model Patterns. J. Ind. Ecol. 2018, 23, 36-61. [CrossRef]

115. Oghazi, P.; Mostaghel, R. Circular Business Model Challenges and Lessons Learned-An Industrial Perspective. Sustainability 2018, 10, 739. [CrossRef]

116. Agyemang, M.; Kusi-Sarpong, S.; Khan, S.A.; Mani, V.; Rehman, S.T.; Kusi-Sarpong, H. Drivers and barriers to circular economy implementation. Manag. Decis. 2019, 57, 971-994. [CrossRef]

117. Heyes, G.; Sharmina, M.; Mendoza, J.M.F.; Schmid, A.G.; Azapagic, A. Developing and implementing circular economy business models in service-oriented technology companies. J. Clean. Prod. 2018, 177, 621-632. [CrossRef]

118. Bag, S.; Gupta, S.; Kumar, S.; Sivarajah, U. Role of technological dimensions of green supply chain management practices on firm performance. J. Enterp. Inf. Manag. 2020, 34, 1-27. [CrossRef]

119. Li, Y.; Dai, J.; Cui, L. The impact of digital technologies on economic and environmental performance in the context of industry 4.0: A moderated mediation model. Int. J. Prod. Econ. 2020, 229, 107777. [CrossRef]

120. Gupta, S.; Chen, H.; Hazen, B.T.; Kaur, S.; Gonzalez, E.D.R.S. Circular economy and big data analytics: A stakeholder perspective. Technol. Forecast. Soc. Chang. 2019, 144, 466-474. [CrossRef]

121. Ostermann, C.M.; Nascimento, L.D.S.; Da Silva, A.R. Business Model Innovation for Circular Economy: A Fashion Industry Perspective. In Proceedings of the XXI ENGEMA Conference, Sao Paolo, Brasil, 4-6 December 2019.

122. Hongwei, Z.; Stuart, M.E.; Yang, L.W.; Richard, W.Y. Computing Handbook: Information Systems and Information Technology, 3rd ed.; CRC Press: Boca Raton, FL, USA, 2014.

123. Piccarozzi, M.; Aquilani, B.; Gatti, C. Industry 4.0 in Management Studies: A Systematic Literature Review. Sustainability 2018, 10, 3821. [CrossRef]

124. Ogbuke, N.J.; Yusuf, Y.Y.; Dharma, K.; Mercangoz, B.A. Big data supply chain analytics: Ethical, privacy and security challenges posed to business, industries and society. Prod. Plan. Control. 2020, 1-15. [CrossRef]

125. Kjaer, L.L.; Pigosso, D.C.A.; Niero, M.; Bech, N.M.; McAloone, T.C. Product/Service-Systems for a Circular Economy: The Route to Decoupling Economic Growth from Resource Consumption? J. Ind. Ecol. 2019, 23, 22-35. [CrossRef]

126. Pal, R.; Shen, B.; Sandberg, E. Circular fashion supply chain management: Exploring impediments and prescribing future research agenda. J. Fash. Mark. Manag. Int. J. 2019, 23, 298-307. [CrossRef]

127. Ik, M.; Azeez, A.A. Organisational Green Behavioural Change: The Role of Change Management. Int. J. Entrep. Knowl. 2020, 8, 34-48. [CrossRef]

128. Jabbour, C.J.C.; Jabbour, A.B.L.D.S.; Sarkis, J.; Filho, M.G. Unlocking the circular economy through new business models based on large-scale data: An integrative framework and research agenda. Technol. Forecast. Soc. Chang. 2019, 144, 546-552. [CrossRef]

129. Kohtamäki, M.; Partanen, J. Co-creating value from knowledge-intensive business services in manufacturing firms: The moderating role of relationship learning in supplier-customer interactions. J. Bus. Res. 2016, 69, 2498-2506. [CrossRef]

130. Nastasiea, M.; Mironeasa, C. Key Performance Indicators in Small and Medium Sized Enterprises. Total Qual. Manag. 2015, 1, 46-53.

131. Hartley, K.; van Santen, R.; Kirchherr, J. Policies for transitioning towards a circular economy: Expectations from the European Union (EU). Resour. Conserv. Recycl. 2020, 155, 104634. [CrossRef]

132. Velte, P.; Stawinoga, M.; Lueg, R. Carbon performance and disclosure: A systematic review of governance-related determinants and financial consequences. J. Clean. Prod. 2020, 254, 120063. [CrossRef]

133. Van Stijn, A.; Gruis, V. Towards a circular built environment. Smart Sustain. Built Environ. 2020, 9, 635-653. [CrossRef]

134. Ciano, M.P.; Dallasega, P.; Orzes, G.; Rossi, T. One-to-one relationships between Industry 4.0 technologies and Lean Production techniques: A multiple case study. Int. J. Prod. Res. 2021, 59, 1386-1410. [CrossRef]

135. Di Nardo, M.; Clericuzio, M.; Murino, T.; Sepe, C. An Economic Order Quantity Stochastic Dynamic Optimization Model in a Logistic 4.0 Environment. Sustainability 2020, 12, 4075. [CrossRef]

136. Danilova, J.; Grant, D.B.; Menachof, D. Investigating SME Participation in the UK Offshore Wind Supply Chain. In 2016 Annual Logistics Research Network (LRN) Conference; CILT UK-The Chartered Institute of Logistics and Transport in the UK: Corby, UK, 2008.

137. Raja, J.Z.; Frandsena, T.; Kowalkowskibc, C.; Jarmatza, M. Learning to discover value: Value-based pricing and selling capabilities for services and solutions. J. Bus. Res. 2020, 114, 142-159. [CrossRef]

138. Turunen, T.; Finne, M. The organisational environment's impact on the servitization of manufacturers. Eur. Manag. J. 2014, 32, 603-615. [CrossRef]

139. Cainelli, G.; D'Amato, A.; Mazzanti, M. Resource efficient eco-innovations for a circular economy: Evidence from EU firms. Res. Policy 2020, 49, 103827. [CrossRef] 
140. Schenkl, S.A.; Sauer, R.M.; Mörtl, M. A Technology-centered Framework for Product-service Systems. Procedia CIRP 2014, 16, 295-300. [CrossRef]

141. Bag, S.; Yadav, G.; Dhamija, P.; Kataria, K.K. Key resources for industry 4.0 adoption and its effect on sustainable production and circular economy: An empirical study. J. Clean. Prod. 2021, 281, 125233. [CrossRef]

142. De Man, J.C.; Strandhagen, J.O. An Industry 4.0 Research Agenda for Sustainable Business Models. Procedia CIRP 2017, 63, 721-726. [CrossRef]

143. Centobelli, P.; Cerchione, R.; Murino, T. Layout and Material Flow Optimization in Digital Factory. Int. J. Simul. Model. 2016, 15, 223-235. [CrossRef]

144. Pero, M.; Moretto, A.; Bottani, E.; Bigliardi, B. Environmental Collaboration for Sustainability in the Construction Industry: An Exploratory Study in Italy. Sustainability 2017, 9, 125. [CrossRef]

145. Wang, N.; Ren, S.; Liu, Y.; Yang, M.; Wang, J.; Huisingh, D. An active preventive maintenance approach of complex equipment based on a novel product-service system operation mode. J. Clean. Prod. 2020, 277, 123365. [CrossRef]

146. Damonte, L.T.; Woodside, A.G. Are lodging revenue cycles leading indicators for shifts in financial well-being? J. Bus. Res. 2021, 129, 465-473. [CrossRef]

147. Chowdhury, S.; Haftor, D.; Pashkevich, N. Smart Product-Service Systems (Smart PSS) in Industrial Firms: A Literature Review. Procedia CIRP 2018, 73, 26-31. [CrossRef]

148. Zucchella, A.; Previtali, P. Circular business models for sustainable development: A "waste is food" restorative ecosystem. Bus. Strateg. Environ. 2019, 28, 274-285. [CrossRef]

149. De Giovanni, P. When feature-based production capabilities challenge operations. Int. J. Oper. Prod. Manag. 2019, 40, $221-242$. [CrossRef]

150. Chen, Z.; Lu, M.; Ming, X.; Zhang, X.; Zhou, T. Explore and evaluate innovative value propositions for smart product service system: A novel graphics-based rough-fuzzy DEMATEL method. J. Clean. Prod. 2020, 243, 118672. [CrossRef]

151. Ünal, E.; Urbinati, A.; Chiaroni, D. Managerial practices for designing circular economy business models. J. Manuf. Technol. Manag. 2019, 30, 561-589. [CrossRef]

152. Lee, C.M.J.; Che-Ha, N.; Alwi, S.F.S. Service customer orientation and social sustainability: The case of small medium enterprises. J. Bus. Res. 2021, 122, 751-760. [CrossRef]

153. Linder, M.; Sarasini, S.; van Loon, P. A Metric for Quantifying Product-Level Circularity. J. Ind. Ecol. 2017, 21, 545-558. [CrossRef]

154. Zhang, Z.; Luo, X.; Kwong, C.K.; Tang, J.; Yu, Y. Return and refund policy for product and core service bundling in the dual-channel supply chain. Int. Trans. Oper. Res. 2017, 26, 223-247. [CrossRef]

155. Rossi, E.; Bertassini, A.C.; Ferreira, C.D.S.; Amaral, W.A.N.D.; Ometto, A.R. Circular economy indicators for organizations considering sustainability and business models: Plastic, textile and electro-electronic cases. J. Clean. Prod. 2020, $247,119137$. [CrossRef]

156. Tebaldi, L.; Bigliardi, B.; Bottani, E. Sustainable Supply Chain and Innovation: A Review of the Recent Literature. Sustainability 2018, 10, 3946. [CrossRef]

157. Yuan, Y.; Azam, S.M.F.; Tham, J. Factors Influencing Enterprise Performance of Small and Medium Size Enterprises (Smes) in Malaysia. Eur. J. Manag. Mark. Stud. 2019, 4, 112-127. [CrossRef]

158. Brown, R.; Lee, N. Strapped for cash? Funding for UK high growth SMEs since the global financial crisis. J. Bus. Res. 2019, 99, 37-45. [CrossRef]

159. Dvouletý, O.; Srhoj, S.; Pantea, S. Public SME grants and firm performance in European Union: A systematic review of empirical evidence. Small Bus. Econ. 2020, 57, 1-21. [CrossRef]

160. Goyal, R. The Question of Economic Choices-Startups: Service Sector vs. Product Sector. Available online: https:/ / economictimes indiatimes.com/tech/startups / piyush-goyal-asks-indian-investors-to-mentor-support-startups-in-bimstec-region/articlesh ow /80283699.cms (accessed on 10 December 2020).

161. Tykkyläinen, S. Why social enterprises pursue growth? Analysis of threats and opportunities. Soc. Enterp. J. 2019, 15, 376-396. [CrossRef]

162. Howard, M.; Caldwell, N.; Smith, L.; Maull, R.; Ng, I.C. Servitization and operations management: A service dominant-logic approach. Int. J. Oper. Prod. Manag. 2014, 34, 242-269. [CrossRef]

163. Gupta, S.; Zeithaml, V. Customer Metrics and Their Impact on Financial Performance. Mark. Sci. 2006, 25, 718-739. [CrossRef]

164. Sousa-Zomer, T.T.; Magalhães, L.; Zancul, E.; Cauchick-Miguel, P.A. Exploring the challenges for circular business implementation in manufacturing companies: An empirical investigation of a pay-per-use service provider. Resour. Conserv. Recycl. 2018, 135, 3-13. [CrossRef]

165. Ejsmont, K.; Gladysz, B.; Corti, D.; Castaño, F.; Mohammed, W.M.; Lastra, J.L.M. Towards 'Lean Industry 4.0' —Current trends and future perspectives. Cogent Bus. Manag. 2020, 7, 1781995. [CrossRef]

166. Bag, S.; Wood, L.C.; Mangla, S.K.; Luthra, S. Procurement 4.0 and its implications on business process performance in a circular economy. Resour. Conserv. Recycl. 2020, 152, 104502. [CrossRef]

167. Ivanov, D.; Tang, C.S.; Dolgui, A.; Battini, D.; Das, A. Researchers' perspectives on Industry 4.0: Multi-disciplinary analysis and opportunities for operations management. Int. J. Prod. Res. 2021, 59, 2055-2078. [CrossRef]

168. Cherry, C.E.; Pidgeon, N.F. Why Is Ownership an Issue? Exploring Factors That Determine Public Acceptance of Product-Service Systems. Sustainability 2018, 10, 2289. [CrossRef] 
169. Matschewsky, J. Effective and Efficient Design and Provision of Product-Service Systems: Challenges, Opportunities, and Solutions. Ph.D. Thesis, Linköping University, Linköping, Sweden, 2019.

170. Ibarra, D.; Ganzarain, J.; Igartua, J.I. Business model innovation through Industry 4.0: A review. Procedia Manuf. 2018, 22, 4-10. [CrossRef]

171. Yang, M.; Smart, P.; Kumar, M.; Jolly, M.; Evans, S. Product-service systems business models for circular supply chains. Prod. Plan. Control 2018, 29, 498-508. [CrossRef]

172. Planellas, M.; Muni, A. Business Model Canvas. Strateg. Decis. 2019, 128-131. [CrossRef]

173. Sassanelli, C.; Seregni, M.; Hankammer, S.; Cerri, D.; Terzi, S. The role of internet of things (IoT) technologies for individualisation and service quality of a PSS. In 21st Summer School Francesco Turco 2016; AIDI-Italian Association of Industrial Operations Professors: Milano, Italy, 2016; pp. 36-41.

174. Centobelli, P.; Cerchione, R.; Singh, R. The impact of leanness and innovativeness on environmental and financial performance: Insights from Indian SMEs. Int. J. Prod. Econ. 2019, 212, 111-124. [CrossRef] 